Revista lus et Praxis, Año 21, No 2, 2015, pp. 19 - 60

ISSN 0717 - 2877

Universidad de Talca - Facultad de Ciencias Jurídicas y Sociales

¿En qué casos el incumpliendo de deberes del matrimonio genera responsabilidad civil?

Prof. Dr. Rodrigo Barcia Lehmann - Prof. Mg. José M. Rivera Restrepo

Trabajo recibido 4 de agosto y aprobado el 1 de diciembre 2014

\title{
¿En qué casos el incumplimiento de deberes del matrimonio genera responsabilidad civil?
}

¿IN WHAT CASES THE BREACH OF DUTIES OF MARRIAGE CREATES LIABILITY?

\author{
Prof. Dr. Rodrigo Barcia Lehmann* \\ Prof. Mg. José M. Rivera Restrepo**
}

\section{RESUMEN}

El presente estudio trata acerca de la procedencia de la responsabilidad civil, a propósito de la infracción de los deberes matrimoniales. En él, se utiliza doctrina y jurisprudencia española, alemana, francesa, italiana, entre otras, y se realiza una revisión acerca de los postulados que se esgrimen en nuestro país sobre el tema.

\section{ABSTRACT}

This study discusses the origin of the liability regarding the offense of marital duties. In it, doctrine and Spanish, German, French, Italian law is used, among others, and reviews about the principles that are put forward in our country on the subject is made.

\section{Palabras clave}

Matrimonio, Indemnización de perjuicios, Responsabilidad, Incumplimiento, Deberes matrimoniales

KEY WORDS

Marriage, Claim for damages, Responsibility, Breach, Marital duties

\footnotetext{
* Licenciado en Ciencias Jurídicas y Sociales, Universidad Central de Chile, 1991; MBA Economía y Dirección Internacional de Empresas, MEDI, Universidad Autónoma de Madrid, 1997; European Master in Law and Economics, Complutense und Hamburg Universität, 1998; Doctor en Derecho Privado, Universidad Complutense de Madrid, 2002; Profesor Titular, Facultad de Derecho de la Universidad FinisTerrae.

Correo electrónico: rbarcia@uft.cl.

** Inició sus estudios en el Instituto Nacional y en la Facultad de Filosofía de la Universidad de Chile. Abogado de la Universidad de Chile y Magíster en Derecho, con mención en Derecho Privado por la Universidad de Chile. Máster Universitario en Derecho Privado por la Universidad Complutense de Madrid. Doctor en Derecho Civil por la Universidad Complutense de Madrid. Profesor de Jornada de Derecho Civil en la Universidad Gabriela Mistral. Ha sido profesor de Derecho Civil en las Universidades de Chile y de Talca. Correo electrónico: jose.rivera@ugm.cl

No podemos dejar de agradecer la invaluable contribución de profesor Gonzalo Ruz en el tratamiento del Derecho francés.

Abreviaruras: $\mathrm{BGB}=$ Bürgerliches GesetzBuCH [Código Civil alemán]; CA = Corte de Apelaciones; CCCh = Código Civil chileno; $\mathrm{CCE}=$ Código Civil español; Code $=$ Código Civil Francés; Codice Civile $=$ Código Civil italiano; LMC = Ley de Matrimonio Civil (Ley No 19.947/2004); LTF = Ley de Tribunales de Familia (Ley No 19.968/2004); TC = Tribunal Constitucional.
} 


\section{Problema de fondo de la responsabilidad civil frente al incumplimiento de deberes extrapatrimoniales}

El problema de fondo, en torno a la pregunta objeto del presente trabajo, es la libertad y la diferenciación entre Derecho y moral. Esta diferencia es fundamental en el Derecho moderno y se remonta a una concepción del Derecho que tiene sus raíces en Tomás de Aquino, que comienza el tortuoso camino que llevará a diferenciar la moral y el Derecho en Occidente. Si supuestos incumplimientos de deberes morales generan indemnización de perjuicios, pondremos un coto en la actuación de la esfera privada de las personas, que en definitiva llevan a la invisibilidad de ciertos comportamientos y transforma la justicia civil en la justicia del Cadí.

En esta materia es precisamente en la que de mejor forma se pueden apreciar los peligros de la excesiva intervención de los jueces en la moral de los individuos (corriente que se ha denominado como neo-constitucionalismo). Esta corriente de pensamiento, generalizada entre nosotros, podría Ilevar a que los jueces estén facultados para poder inmiscuirse en el fuero interno de las personas, dando lugar a una prueba en que se ventilan los aspectos más íntimos y difíciles de resolver del ser humano. Los jueces, de esta forma, pueden calificar el comportamiento de las personas como de "bueno" o "malo" e incidir en su conducta a través de la indemnización de perjuicios. Esto se puede apreciar en el caso más relevante, en que eventualmente se podría aplicar la responsabilidad civil por incumplimiento de deberes del matrimonio, como lo es la infidelidad. Y ello es evidente porque si se admite el daño moral por incumplimiento del deber de fidelidad en el matrimonio, ¿por qué no admitirlo en las relaciones de otra índole en que haya un compromiso entre las parejas no casadas? o en general ifrente a cualquier incumplimiento de un deber jurídico/ético? Como se aprecia de estas preguntas estamos ingresando en un área respecto de la cual el Derecho moderno, o posmoderno, ha tenido el cuidado de no invadir, como es la privacidad y dignidad del ser humano. El peligro de la excesiva intervención judicial es llevarnos a confundir una vez más moral y Derecho, por ello es tan importante limitar la intervención judicial a casos claros y definidos. Como este es un trabajo de Derecho civil esta será nuestra tarea.

Estos planteamientos han llevado a una oposición fuerte a siquiera admitir la posibilidad de dar lugar a la responsabilidad civil por incumplimiento de deberes extrapatrimoniales y concretamente de los deberes del matrimonio. Esta posición nos parece comprensible, pero es, sin lugar a dudas, un tanto extrema. Por lo que el presente trabajo buscará -admitiendo los problemas que genera la aplicación lisa y llana de la responsabilidad civil al incumplimiento de los deberes en el matrimonio- desarrollar una teoría que aleje los peligros de una excesiva intervención del Estado en la familia. Así, no nos satisfacen, ni 
las posiciones que niegan de forma tajante tal posibilidad", ni las que la admiten lisa y llanamente ${ }^{2}$.

\section{Falso planteamiento del problema de la aplicación de la responsabilidad civil al incumplimiento de los deberes del matrimonio}

No estamos de acuerdo con algunas doctrinas que señalan como fundamento de la responsabilidad civil general, en materia de incumplimiento de deberes no patrimoniales, un supuesto sustento igualitario o de ampliación de la frontera de la responsabilidad civil $^{3}$. También se ha señalado que la negación de una responsabilidad general implica una consagración del abuso al interior de la familia. Así, se ha planteado que los que niegan tal posibilidad se adscriben a la tesis de la "inmunidad de responsabilidad" en la familia ${ }^{4}$. En este sentido, el Derecho exige a sus integrantes un comportamiento jurídico, que es no dañar a otro ${ }^{5}$.

Una segunda vertiente de autores, adscribiéndose a la posición anterior, buscan aplicar la indemnización de perjuicios como un disuasivo en torno al

\footnotetext{
1 No son pocos los autores que están en principio en contra de dicha posibilidad, como SeVERín (2008), pp. 99-140 Y TURNER (2012), pp. 165-173.

2 Tampoco son pocos los autores que se inclinan a favor de la aplicación de las reglas de la responsabilidad extracontractual al Derecho de Familia, con matices por cierto. Ruz (2009), pp. 672-677; Domínguez (2010), pp. 671-685; Larrocau (2010), pp. 99-124; Barrientos (2011), p. 563 y Otárola (2012), pp. 125-134.

Naturalmente, la doctrina decimonónica se oponía a ello, por dos clases de razones: la primera era inconfesada y consistía en la forma de entender al matrimonio, que era un terreno en el cual primaba el poder del marido, a través de la potestad marital; y la segunda, más actual por cierto, es que la lógica del Derecho de Familia es diversa al Derecho Patrimonial. Así, la aplicación, sin más del Derecho Patrimonial a las relaciones de familia era un absurdo, como si un marido hubiese exigido que su mujer cumpliera a la fuerza con el deber de seguirlo en su domicilio o el deber de tener relaciones sexuales. Sin embargo, autores, como Claro SOlAR y Meza Barros, señalaban que el incumplimiento a ciertos deberes del matrimonio generaban consecuencias, aunque ellas no eran la indemnización de perjuicios, ni menos el cumplimiento forzado. En este sentido, Claro SOlar señalaba que el incumplimiento del deber de cohabitación o a seguir el domicilio del marido, por parte de la mujer, daba lugar a la pérdida de su deber de alimentos que recaía sobre el marido. Así, también lo entendían los tribunales en los tiempos de Claro Solar. Por otra parte, Meza Barros, estando de acuerdo con la idea precedente, indicaba que si el marido no aceptaba en el hogar común a su mujer, ésta tenía a su favor un derecho de alimentos. Véase, Claro (1992), pp. 30-31 y Meza (1979), pp. 82-83.

3 Medina (2008), pp. 9-11.

${ }^{4}$ Esta doctrina proviene de los Estados Unidos de América, Corte de Mississippi, "Hewellette vs. Geor$g^{\prime \prime}$ (1891). VARGAS destaca que esta teoría habría sido planteada por BLACKSTONE y que se sustenta en la unidad de la familia en cuanto a que hombre y mujer son uno solo en el matrimonio. De esta forma, esta posición tendría un sustento bíblico (GÉNESIS 2:24). A ello se sumaba el derecho a disciplinar física y moderadamente a la mujer. Véase VARGaS (2009), pp. 107-109. En este mismo sentido: Roca I TRÍAs (2000), pp. 534-535 y ROMERO (2009), p. 35.

${ }_{5}^{5}$ Medina (2008), pp. 8-9.
} 
divorcio, no sólo aplicándolo al divorcio culpable, sino también al divorcio unilateral por separación de cuerpos. A esta vertiente en Chile se adscribe Valenzuela, que señala "[...] la indemnización de perjuicios también debería ser admisible por un ejercicio abusivo del derecho a pedir el divorcio por mero cese de la convivencia (divorcio unilateral o divorcio-repudio). Es abusivo el ejercicio de esta prerrogativa cuando excede los límites sociales que se consideran aceptables y cuando hay una grave desproporción entre la utilidad del titular y los perjuicios del sujeto pasivo" ${ }^{\prime 6}$. En igual sentido se puede consultar a Otárola cuando sostiene que el mantener una relación extramatrimonial supone culpa y un ataque a los bienes extrapatrimoniales del otro cónyuge ${ }^{7}$.

Para esta doctrina es naturalmente aplicable la responsabilidad civil para los casos de incumplimiento de deberes extrapatrimoniales, como el incumplimiento a los deberes del matrimonio; y la responsabilidad civil debe proceder frente a cualquier incumplimiento. Estos autores, una vez despejado este problema, consecuentemente con ello, simplemente comienzan a analizar los elementos que integran la responsabilidad civil. Es curioso notar la falta de rigurosidad en el planteamiento precedente, por cuanto se recurre a autores como Claro Solar, que defendía, que los deberes en el matrimonio debían engendrar obligaciones perfectas y no sólo deberes morales, entregados a la conciencia, por cuanto el matrimonio era un contrato. Pero, el matrimonio no es un contrato, como se puede apreciar respecto de los deberes del matrimonio, por cuanto la mayoría son inejecutables. Así, señalado esto, ante la imposibilidad de aplicar las reglas de la responsabilidad contractual, se recurre al estatuto de la responsabilidad extracontractual, y se generaliza la tesis de una amplia responsabilidad civil, en sede extracontractual, por incumplimiento de deberes extrapatrimoniales, y consecuentemente matrimoniales.

\section{Planteamiento realista del problema de la responsabilidad civil al incumplimiento de los deberes del matrimonio}

¿Por qué la posición precedente no es del todo convincente? Fundamentalmente por dos razones. La primera es que los deberes extrapatrimoniales no son, por regla general, ejecutables, y segundo porque estas concepciones, tan generales, confunden ética y Derecho en un sentido inaceptable en un Estado de Derecho ${ }^{8}$. A pesar que lo anterior obedece a un planteamiento mucho más general, ello

${ }^{6}$ Valenzuela (2012), p. 266.

7 OtÁrola (2012), p. 133.

${ }^{8}$ El TS, como destaca VARGAS, mediante una sentencia de 4 de diciembre de 1959, reconoce que los deberes del matrimonio, son deberes jurídicos, pero no son ejecutables. En este sentido su sanción es tenue. VARGAS (2009), pp. 128 y 129. 
se ve reflejado en el principio de la intervención mínima del Estado en la familia. No es que el Estado no pueda intervenir en la familia, sino que cuando lo hace debe ser cuidadoso. Por esta razón, el incumplimiento a deberes del matrimonio, y en general el incumplimiento de deberes extrapatrimoniales, sólo traen aparejados los efectos que el propio ordenamiento jurídico establece. La regla general es que estos deberes, como los deberes de convivencia o de mantener relaciones sexuales en el matrimonio, no sean ejecutables. Esto no es nuevo en el Derecho de Familia. De este modo, tempranamente se estimó por tribunales que el deber de la mujer casada de seguir el domicilio de su marido o la facultad de corrección de los padres para con sus hijos no eran ejecutables, independientemente incluso del texto de la ley ${ }^{9}$. En contra de esta posición Vargas, recurriendo a la doctrina española, señala que la calidad de deberes jurídicos y no tan solo morales, de los deberes que se desprenden del matrimonio, son una consecuencia de su inmodificabilidad e indisponibilidad por parte de los esposos o cónyuges ${ }^{10}$.

A pesar que compartimos el juicio de Vargas, en torno a que estamos en presencia de deberes jurídicos, no podemos dejar de señalar que el que un deber no sea modificable no lo hace jurídico, por cuanto los deberes morales, en tanto tales, son verdaderamente inmodificables en un sentido incluso más estricto que para el Derecho. Esto se puede apreciar de una serie de deberes como no matarás, no desearás a la mujer de tu prójimo, etc., son máximas naturalmente indisponibles.

El rechazo a la aplicación lisa y llana de la responsabilidad civil por incumplimiento de los deberes del matrimonio se evidencia aún más en el Derecho

\footnotetext{
${ }^{9}$ En el ex-artículo 233 del CC, que entró en vigencia con la promulgación de dicho cuerpo legal, se establecía que "[e]l padre tendrá la facultad de corregir i castigar moderadamente a sus hijos, y cuando esto no alcanzare, podrá imponerles la pena de detención hasta por un mes en un establecimiento correccional". La referida norma agregaba en sus incisos $2^{\circ}$ a $4^{\circ}$ que "[b]astará al efecto la demanda del padre, y el juez en virtud de ella expedirá la orden de arresto. Pero si el hijo hubiere cumplido diez y seis años, no ordenará el juez el arresto, sino después de calificar los motivos, y podrá extenderlo hasta por seis meses a lo más. El padre podrá a su arbitrio hacer cesar el arresto". Este artículo fue modificado por la Ley $N^{\circ} 4.447 / 28$, siendo su nueva redacción del siguiente tenor: "Artículo 233. El padre tendrá la facultad de corregir y castigar moderadamente a sus hijos. Cuando lo estimare necesario, podrá recurrir al tribunal de menores, a fin de que éste determine sobre la vida futura del menor por el tiempo que estime más conveniente, el cual no podrá exceder del plazo que le falte para cumplir veinte años de edad. La resolución del juez de menores no podrá ser modificada por la sola voluntad del padre". A su vez, la Ley № 18.802 volvió a modificar la norma precedente preceptuando lo siguiente: "Artículo 233. Los padres tendrán la facultad de corregir y castigar moderadamente a los hijos. Cuando lo estimaren necesario, podrán recurrir al tribunal de menores, a fin de que éste determine sobre la vida futura del menor por el tiempo que estime más conveniente, el cual no podrá exceder del plazo que le falte para cumplir veinte años de edad. Las resoluciones del juez de menores no podrán ser modificadas por la sola voluntad de los padres".

10 VARGAS (2009), pp. 139-144.
} 
matrimonial chileno en el que las consecuencias del incumplimiento de deberes extrapatrimoniales producen efectos particulares. De este modo, a través de la compensación económica se protegen los acuerdos implícitos en el seno de la familia (artículos 61 y 62 de la $L M C C^{11}$; el incumplimiento a los alimentos impide solicitar el divorcio (art. 55.3 ${ }^{\circ}$ de la $L M C$ ), otorga derecho a la mujer a solicitar la separación de bienes (artículo 155 del CCch) y cesa la obligación de alimentos recíprocos (artículo 160 del CCch), etc.

Lo anterior, sin embargo, no quiere decir que ciertas circunstancias no puedan traer aparejadas como consecuencia una indemnización de perjuicios; pero como el sentido común y una parte importante de la doctrina señala, el incumplimiento debe ser de una entidad superior a la mera transgresión de un deber propio del estatuto matrimonial, de filiación o cualquiera que éste sea ${ }^{12}$. Antes de seguir con esta línea de argumentación, resumiremos los argumentos a favor y en contra de admitir la indemnización de perjuicios por incumplimiento de deberes del matrimonio.

\section{III.1. Argumentos en contra de la aplicación de la responsabilidad civil al incumplimiento de los deberes del matrimonio:}

a. La calificación de cónyuge culpable sólo genera las consecuencias establecidas de forma directa en la ley, como dar lugar al divorcio culpable o afectar el "quantum" de la compensación económica en el caso de actuar uno de los cónyuges de mala $\mathrm{fe}^{13}$.

b. Los principios de la intervención mínima del Estado y protección y unidad de la familia impiden que se establezca como regla general la indemnización de perjuicios como incumplimiento a los deberes del matrimonio ${ }^{14}$. No es del caso desarrollar los principios precedentemente señalados, ni explicar por qué

11 Barcia y Riveros (2011a), pp. 249-278; (2011b), pp. 93-113.

12 En este sentido, se ha señalado que "[e]l incumplimiento del deber conyugal, sólo genera responsabilidad civil si es de tal magnitud que, a través de él, se dañen derechos fundamentales o bienes de uno de los cónyuges, y siempre y cuando sea doloso". ROMERO (2008), p. 31.

${ }^{13}$ En Chile, Severín desarrolla magistralmente este punto por cuanto muchas de las causales de divorcio culpable no pueden ser calificadas ni siquiera como anti-jurídicas en otros contextos, como ocurre con el alcoholismo crónico o el homosexualismo, que son causales de divorcio culposo, por lo que malamente el divorcio «per se» podría llevar a la indemnización de perjuicios por incumplimiento grave de los deberes del matrimonio. Sin embargo, contextualizadas dichas situaciones sí que podrían conducir a una indemnización de perjuicios. Como si una madre o un padre alcohólicos dañen gravemente a sus hijos, producto de su conducta bajo la influencia del alcohol, negándose además a someterse a un tratamiento de rehabilitación. Severín (2008), pp. 123-124.

${ }^{14}$ En el Common Law, se hablaba de la "interpousal immunity" y de la "parental immunity". Ésta última, originada en la jurisprudencia de USA (casos "Hewellette vs. George" de 1891, "McKelvey vs. McKelvey" de 1903 y "Roller vs. Roller" de 1905), se funda en la especialidad del Derecho de Familia y en la mantención de la paz y armonía en la familia. Véase, VARGAS (2009), pp. 20-21. 
el Derecho de familia e infancia -dentro del cual opera el Derecho del matrimonio- es un Derecho de principios en el cual la integración del Derecho debe hacerse conforme a máximas, reglas, principios y normas. Pero tal vez la crítica más fuerte contra la aplicación automática de la responsabilidad civil a la infracción estatutaria del matrimonio, como ya hemos planteado, es que dicha posición genera un intervencionismo judicial excesivo ${ }^{15}$.

c. El Derecho no entra a analizar los errores que las personas pueden haber cometido en la vida, que caen en el fuero interno, como puede ser la mala elección del cónyuge o de la pareja ${ }^{16}$.

d. Los deberes del matrimonio son jurídicos, pero no generan los efectos de las obligaciones ${ }^{17}$.

e. El principio de especialidad ${ }^{18}$ impide que la transgresión a un deber del matrimonio lleve aparejada consecuencias jurídicas distintas a las previstas por el ordenamiento jurídico ${ }^{19}$. Así, Ruz agrega que la reparación integral del daño tiene por objeto eliminar el perjuicio patrimonial de la víctima o el acreedor, pero en el Derecho de Familia lo que hay detrás de los deberes es una pretensión de cumplimiento. Lo que se busca es que se cumpla con ciertos estándares éticos, y la reparación se presenta en este sentido como algo no buscado por el Derecho $^{20}$. Mendoza Alonso señala que en el Derecho de Familia, los cónyuges estarían amparados por un estatuto de derechos y deberes específico que, al ser alterados por las normas sobre responsabilidad civil, atentarían contra el interés de la familia, bajo una perspectiva puramente individualista ${ }^{21}$.

15 BARCIA (2011c), pp. 26-27 y 392-393.

${ }^{16}$ A este respecto Romero expresa que: "[e]s curioso, sin embargo, constatar que hay un grupo de autores que basan la negativa a la indemnización o reparación entre cónyuges por incumplimiento de deberes conyugales en lo que ellos denominan "errores de elección". Se pronuncian en este sentido, Bidart Campos, Salvador Coderch y Ruiz García [...]". Romero (2011), p. 41.

17 Romero Coloma señala que: "[l]a naturaleza de la relaciones de familia suelen generar vínculos de solidaridad y altruismo contrarios a la formulación de reclamaciones jurídicas entre las partes afectadas". ROMERO (2008), p. 27.

${ }^{18}$ En dicho orden de ideas, se ha señalado que: "[l]as soluciones a los problemas familiares deben buscarse dentro del Derecho de familia [...]". Algarra (2012), p. 13.

19 Por vía de ejemplo se puede mencionar la sentencia del TS de 30 de julio de 1999. La demanda fue motivada por una acción de impugnación presentada por la madre, en contra del marido, una vez declarado el divorcio por cese efectivo de la convivencia e infidelidad de la mujer. El demandante alega daños morales y patrimoniales. El TS niega la demanda, por estimar que no caben dentro del artículo 1101 del Código Civil español, cuestión que está regulada por el artículo 82 del mismo cuerpo legal (dar lugar a la separación matrimonial). Véase, ROMERO (2011), p. 23.

${ }^{20}$ Ruz (2009), p. 676.

21 Mendoza (2011), p. 47. 
f. A pesar que esta indemnización incentiva a que los cónyuges no se divorcien, en definitiva castiga a los que se casan. Por ello se generan dos incentivos, por una parte los que contraen el matrimonio no pueden desvincularse del estatuto matrimonial, sin sufrir un alto costo por ello, y por la otra, los que pueden ingresar no lo hacen por temor a los costos del ingreso.

g. La prescripción extintiva no corre entre cónyuges (artículo 2509 del CCch).

h. En Italia y España ${ }^{22}$, existe una cierta tendencia, animada por la costumbre social, en entender que los perjuicios familiares no pueden ser objeto de una demanda de indemnización de daños y perjuicios. Así, se reconoce una suerte de principio de inmunidad entre familiares. Sin perjuicio de lo cual, dicho principio, como veremos, ha comenzado a resquebrajarse ${ }^{23}$.

j. No es que en la mayoría de los ordenamientos jurídicos, que no se pronuncian sobre esta materia, exista un vacío regulatorio, sino que una decidida opción por no aplicar las reglas de la responsabilidad civil al incumplimiento de deberes del matrimonio ${ }^{24}$.

\section{III.2. Argumentos a favor de la aplicación de la responsabilidad civil al incumplimiento de los deberes del matrimonio}

a. No es admisible que la violación de derechos fundamentales sea resarcible fuera de la familia, o en el matrimonio, y no en su interior ${ }^{25}$.

b. Esta posición incentiva la estabilidad del matrimonio, por cuanto ex-ante evita la ruptura.

\footnotetext{
22 Mendoza (2011), pp. 42-43.

${ }^{23}$ RodríGuez Guitán señala como posibles argumentos que excluyen a la indemnización de perjuicios en el ámbito familiar, los siguientes: (1) Existencia de una regla de moralidad que impide la interposición de una demanda de responsabilidad civil entre los miembros de una familia. (2) El modelo de familia que recogen los códigos civiles decimonónicos. (3) Existencia de barreras institucionales impuestas por el propio Código civil. (4) El carácter ético o moral de los deberes familiares. (4) El peligro de proliferación de demandas triviales y el aumento de la conflictividad en el seno de la familia. (6) La indemnización de los daños entre familiares no cumple las funciones propias de la responsabilidad civil, y (7) Aplicación exclusiva y excluyente de las normas del Derecho familiar para resolver los daños entre los integrantes de la misma. RodríGuez (2009), pp. 33 y ss.

24 Sáinz-Cantero y Pérez (2012), pp. 4-5.

${ }^{25}$ En Venezuela, Domínguez se pregunta, a propósito de la posibilidad de demandar indemnización de daños y perjuicios, a un progenitor que incumple su derecho-deber de filiación. Al respecto, la autora señala que: "[...] puede responder patrimonialmente por dicha omisión como consecuencia necesaria de una acción por daños y perjuicios, pues hemos reiterado que las relaciones de familia no escapan de las normas generales sobre responsabilidad civil". Domínguez (2012), pp. 289-290. Por su parte, Marín García De LeOnardo, en España, señala que: "[l]as normas específicas del Derecho de Familia no pueden impedir la defensa de los derechos de los que goza un cónyuge como persona [...]". ROMERO (2011), p. 28.
} 
c. No existe norma en materia de Derecho de Familia que impida la aplicación de la responsabilidad civil $^{26}$.

d. La posición anterior obedece a la regulación dispuesta por la mayoría de los códigos decimonónicos, que, alentados por una economía de carácter agrícola, de auto-subsistencia y trabajo gratuito entre los integrantes de la familia, no regularon la posible acción indemnizatoria entre familiares y cónyuges. Ello, a pesar que, como nos señala Díez-Picazo, desde el punto de vista filosófico, se consagró igualmente el principio individualista ${ }^{27}$.

e. Los derechos-deberes en materia familiar, como el deber de fidelidad y ayuda mutua en el matrimonio, aun cuando se fundamentan en normas mora$\mathrm{les}^{28}$, son a la vez verdaderos deberes jurídicos, participando de las características propias de éstos ${ }^{29}$.

f. El hecho que las normas del Derecho de Familia tengan el carácter de especiales $^{30}$, no puede servir como excusa para eludir las normas generales del Derecho de Daños ${ }^{31}$.

La enumeración precedente no es exhaustiva, y tampoco se desarrolla en profundidad, pero algunos de estos argumentos serán tratados en detalle a continuación.

La verdad es que ninguno de los argumentos señalados precedentemente nos parecen definitivos, por cuanto el Derecho de Daños no se puede aplicar lisa y llanamente al incumplimiento de un deber matrimonial, entendido como un ilícito imputable que tiene su sustento en una infracción estatutaria; pero tampoco parece razonable que, bajo cualquier circunstancia, no exista responsabilidad civil por incumplimiento de deberes del matrimonio. Es indispensable hacer disquisiciones que nos Ileven a poder establecer algunos criterios que determinen los límites a la responsabilidad civil respecto del incumplimiento de deberes del matrimonio. Para ello primeramente recurriremos a la dogmática comparada.

\footnotetext{
${ }^{26}$ VARGAS (2009), p. 32.

27 RodríGuez Guitán (2009), pp. 40-41.

${ }^{28}$ En este sentido, Romero señala que: "[d]esde luego, el peligro de multiplicidad de pleitos y la preservación de la paz familiar no deben alegarse para excluir toda responsabilidad civil [...]". ROMERO (2008), p. 31.

29 Romero (2011), p. 17.

${ }^{30}$ A este respecto, AlgarRa señala que: "[e]l Derecho de familia no es un conjunto de normas absolutamente cerrado y de aplicación exclusiva y excluyente, sino que debe abrirse al Derecho de daños cuando éstos efectivamente se produzcan [...]". AlgarRa (2012), p. 13.

31 Romero (2011), p. 29.
} 


\section{Situación del Derecho Comparado}

Casos de incumplimientos derivados del matrimonio, como la aplicación maliciosa de la presunción "pater is est" ${ }^{\prime 32}$; el incumplimiento al deber de fidelidad o el incumplimiento de deberes extrapatrimoniales del Derecho de Familia de carácter general, como la negativa al reconocimiento de la filiación ${ }^{33}$, no cumplimiento u obstrucción al régimen de relación directa y regular $(R D R)$, incumplimiento del deber de alimentos, supresión ilegal de la identidad, nacimientos defectuosos, transmisión de enfermedades contagiosas, el no dar a conocer el origen biológico por parte de los padres adoptivos, dejar a una criatura en una situación de desamparo (madre que abandona su hijo), etc., han dado lugar, en otras latitudes, a una indemnización de perjuicios entre cónyuges, entre padres no casados, entre parejas y entre madres o padres e hijos.

La doctrina y jurisprudencia comparadas, que han admitido la responsabilidad precedente, han resuelto que el estatuto que se aplica en estos casos es el de la responsabilidad extracontractual. Sin embargo, la responsabilidad contractual es un sistema más coherente con un estatuto general de responsabilidad por incumplimiento de deberes matrimoniales; pero, como ya se vio, tal posibilidad está vetada, por absurda. Por ello nos inclinamos claramente, siguiendo al Derecho comparado, a favor de la responsabilidad extracontractual. Pues bien, el elemento clave en torno a la aplicación de la responsabilidad extracontractual, al incumplimiento de los deberes del matrimonio, es la ilicitud del hecho. La imputabilidad, aunque naturalmente relevante, no es lo determinante en esta responsabilidad, porque antes de analizar si el marido o la mujer o el padre o la madre han actuado con culpa o dolo, incurriendo en algún criterio de imputabilidad objetiva, se debe analizar si la conducta es ilícita, y para estos efectos no basta con la mera violación estatuaria, como si una mujer o un hombre son calificados como cónyuge culpable en el divorcio ${ }^{34}$. No es tan simple. A favor de este análisis se puede recurrir a los casos en que se admite la indemnización en el Derecho de Familia y Sucesorio. Y ellos se pueden calificar como casos de ilicitud exacerbada, que exceden la transgresión del respectivo estatuto. También nos parece correcto que la responsabilidad provenga por aplicación de criterios de imputabilidad agravados. Así, entre

\footnotetext{
32 En Italia, "[l]a violación de un deber conyugal puede determinar un daño resarcible, aparte de los remedios propios del derecho de familia, cuando el mismo derive de la lesión de intereses fundamentales de la persona merecedores de tutela, como la salud, el honor o la integridad moral". Atgarra (2012), p. 26.

33 Véase Bustos (2012), pp. 129-159.

${ }^{34}$ En todo caso en la actualidad la imputabilidad se suele asimilar a la ilicitud y a la aniti-juricidad. La culpa en este sentido es calificada como una infracción estatutaria. Así, BARros nos señala que "...se ha definido la culpa como ilicitud, esto es, como la conducta contraria a derecho". BARROS (2006), p. 95.
} 
nosotros, se puede consultar el artículo 197 del CCCh que establece una acción de indemnización de perjuicios por entablar una acción de filiación de mala $\mathrm{fe}^{35}$ o el artículo 328, del mismo cuerpo legal, respecto de los alimentos obtenidos con dolo ${ }^{36}$; etc. Es verdad que estas normas se refieren al Derecho de Familia en general y no al matrimonial, pero la solución aplicable al Derecho matrimonial naturalmente puede provenir del Derecho de Familia en general. También coincidimos con los autores que señalan que estas reglas no pueden llevarnos a concluir que el legislador ha establecido la imposibilidad absoluta de recurrir a la indemnización de perjuicios respecto del incumplimiento de los deberes del matrimonio. El planteamiento que recogemos es admitir la indemnización de perjuicios de forma excepcional, es decir, no permitir una aplicación general de la responsabilidad extracontractual al incumplimiento de deberes ético-jurídicos, sino acogerla sólo para ilícitos agravados y no como una simple aplicación mecánica de un ilícito infraccional, como lo sería si la responsabilidad civil proviniera de una sentencia que declara a un cónyuge como culpable en el divorcio ${ }^{37}$.

\section{IV.1. Aplicación de la responsabilidad civil extracontractual al incumplimiento de deberes del matrimonio}

En España, la doctrina por regla general se inclina a favor de tal posibilidad ${ }^{38}$, es dable mencionar, en este sentido, a Lacruz Berdejo, Sancho Rebullida, Lete Del Río, Gete-Alonso y Calera, García Cantero, Tagel Sánchez, Alonso Pérez, Pérez Mayor e Igartua Arregui ${ }^{39}$; aunque existen autores que están en contra como Salvador Coderch, Ruiz García ${ }^{40}$, Ramos Chaparro, Serrano Gómez,

\footnotetext{
${ }^{35}$ A este respecto, el artículo 197.2 $2^{\circ}$ del CCCh establece que "[l]a persona que ejerza una acción de filiación de mala fe o con el propósito de lesionar la honra de la persona demandada es obligada a indemnizar los perjuicios que cause al afectado".

36 Por su parte, el artículo 328 CCCh dispone que: "[e]n el caso de dolo para obtener alimentos, serán obligados solidariamente a la restitución y a la indemnización de perjuicios todos los que han participado en el dolo".

37 En España, existen casos en que se prevé por el ordenamiento jurídico una forma de indemnización específica para resarcir los daños y perjuicios entre familiares, aun cuando, se enmarcan dentro del Derecho familiar patrimonial (el cónyuge que se aprovecha del lucro de forma exclusiva, la generación dolosa de un perjuicio de la sociedad de gananciales y los actos ejecutados con la intención de defraudad al otro cónyuge). RodríGuez (2009), pp. 102 y ss.

${ }^{38}$ VARGAS (2009), p. 21.

39 Romero (2011), p. 43. Véase también, Rodríguez (2011), pp. 1 y ss.

40 Vargas Aravena (2009), p. 38.
} 
Ferrer Riba ${ }^{41}$ y Rodríguez Guitán ${ }^{42}$. El precursor de la opinión imperante fue Lacruz Berdejo, quien, al analizar el artículo 68 del CCE (antes de la reforma del 2005), tipificaba al adulterio como la infracción más grave en esta materia, dando lugar a una indemnización de daños y perjuicios por afectar la dignidad y sentimientos del cónyuge inocente, sobre la base del ex-artículo 104 del Código penal español, y que otorgaba acción indemnizatoria no sólo por los daños que se provocaren a la víctima ${ }^{43}$, sino también a su familia ${ }^{44}$.

En Francia ${ }^{45}$, Italia ${ }^{46}$ y Argentina se admite la indemnización por incumplimiento de deberes del matrimonio. En sede extracontractual, el debate en Francia se ha centrado en la posibilidad de reclamar perjuicios en caso de infidelidad matrimonial. La doctrina mayoritaria ha tendido a "privatizar" el deber de fidelidad, estableciendo que procede, en esta materia, la acción indemnizatoria, conforme al mencionado artículo 1382 del Code ${ }^{47}$.

La Reforma francesa del 2004 nos parece que fue un avance en la regulación de la indemnización por los perjuicios que genera el divorcio ${ }^{48}$. La demanda de indemnización de perjuicios, conforme a esta nueva reglamentación, se da en dos supuestos. El primero, como se analizará, opera a favor de uno de los cónyuges, en reparación de las consecuencias particularmente graves sufridas por el hecho de la disolución del matrimonio, cuando hubiera sufrido una demanda de divorcio por alteración definitiva del vínculo conyugal sin haber

${ }^{41}$ Véase, Ferrer (2001), pp. 3 y ss.

42 Romero (2011), p. 17.

43 Romero (2011), pp. 43-44.

${ }^{44}$ En España, la sentencia del TS de 30 de junio de 2009, le concede una indemnización de daños y perjuicios al padre, que vio afectado su derecho de visitas, por el traslado (sin su consentimiento) de la madre y su hijo a Florida. Ramos (2012), p. 398.

45 LÓPEZ DE LA CRUZ señala, respecto de Francia, que: "[e]n la jurisprudencia, es destacada por los autores la sentencia de la Corte de Casación de 9 de noviembre de 1965, en la que, aplicándose los principios del Derecho de daños, se concede una indemnización a la esposa por los perjuicios sufridos como consecuencia de la negativa de su marido a admitirla en el domicilio conyugal. La Corte de Casación anuló la sentencia del Tribunal de apelación que rechazaba la petición de la esposa por no haberse tramitado la separación o el divorcio a la vez que se solicitaba el resarcimiento del daño". LópEZ DE LA CRUz (2010), p. 16.

${ }^{46}$ En Italia, a fines de la década de los 80, comienza a reconocerse la indemnización de daños en materia familiar, particularmente con la sentencia 184/1986 de 14 de julio, que ordena indemnizar el daño a la "vita di relazione" y el perjuicio estético en la persona. Confróntese, LóPEZ DE LA CRUZ (2010), p. 18.

47 Algarra (2012), pp. 17-18.

${ }^{48}$ La opinión contraria manifiestan Terre y Fenoulletet, que critican la Reforma del 2004 por considerarla un retroceso en los alcances de la indemnización de perjuicio. TerRe y FenOuillet (2005), p. 480. 
formulado, a su vez, ninguna demanda de divorcio ${ }^{49}$. El segundo supuesto procede también exclusivamente por divorcio, cuando éste se hubiere declarado por culpa exclusiva del cónyuge demandado.

La acción de daños del artículo 266 del Code se produce exclusivamente por disolución del matrimonio. Antes de la Reforma del 2004, el artículo 266 del Code sólo exigía la culpabilidad del cónyuge; en la actual regulación se exige, además, que se reparen consecuencias "particularmente graves" ${ }^{\prime 50}$ que se produzcan como consecuencia de la disolución del matrimonio producido por el divorcio. La norma precitada, sin embargo, no es incompatible con la regla general del artículo 1382 del mismo cuerpo legal, toda vez que se trata de una norma especial cuya aplicación se enmarca dentro de los efectos que genera el divorcio ${ }^{51}$. Así, en el Derecho francés, no se ha postulado la impunidad de los daños causados en el matrimonio, aceptándose la reparación de los perjuicios derivados de las relaciones de familia, sobre la base de la aplicación del artículo 1382 del Code $^{52}$, no existiendo ninguna clase de

${ }^{49}$ La determinación de los daños, por lo que se condena a un cónyuge, deben ser fundados. No basta con señalar las circunstancias, sino que la gravedad debe ser acreditada. Así, la Reforma del 2004 al exigir que dicho daño debe provenir de "las consecuencias particularmente graves sufridas por el hecho de la disolución del matrimonio" aumenta las exigencias para dar lugar a la indemnización de perjuicios. Ver: Cass. civ. 1 re, 1 er juillet 2009.

50 Bénabent (2010), pp. 256-257. Como señala el profesor Massip (Petites affiches, 28 janvier 2010, № 20, p. 11) comentando un fallo de la primera sala civil de la Corte de casación de $1^{\circ}$ de julio de 2009 , la nueva redacción del art. 266 amplía y al mismo tiempo restringe la anterior disposición. Por una parte la amplía porque la anterior sólo consideraba los casos de divorcio por culpa, esta nueva redacción también incluye los casos de divorcio por cese de convivencia. Por otra parte, la restringe, pues los perjuicios reparables son sólo aquellos de una particular gravedad. El nuevo texto, sin embargo, no precisa, como el antiguo, si la extensión de los daños a reparar incluyen también el daño material y el moral, sin embargo concluye que debe admitirse que, redactado en esos términos generales, el nuevo texto contribuye a cubrir los dos tipos de perjuicios.

51 Sin embargo, la Corte de casación francesa también ha dispuesto (Cass. Civ. 6 de marzo de 2013 $\mathrm{N}^{\circ}$ 12.12.338), que esta compatibilidad no permite que el actor invoque ambos estatutos al mismo tiempo, uno en subsidio del otro. En el caso en cuestión, la Corte de Apelaciones de Aix-en-Provence en fallo de 20 de diciembre de 2010, había rechazado la demanda de perjuicios de la actora señalando que no había probado que la falta atribuible al marido era de una particular gravedad, en los términos que exige el art. 266; sin embargo, de oficio considera que el perjuicio atribuible a la falta podía ser reparado bajo el art. 1382 y otorga a la actora una indemnización de 5.000 euros. La Corte de Casación censura la sentencia de la corte de apelaciones bajo el fundamento que ésta última ha modificado el objeto del litigio (violación de los arts. 4, 12 y 16 del CPC). La doctrina que se extrae entonces es que los dos textos no pueden ser utilizados uno en subsidio del otro, pueden obtenerse reparaciones fundadas en los dos estatutos pero no emplearlas de manera alternativa, una para el caso que no sea acogida la otra. Lo anterior no obsta, como lo sentenció la propia Corte de casación en un fallo de la segunda sala civil de 30 de noviembre de 2000 ( $N^{\circ}$ 98.19.141), que la aplicación de ambos textos (arts. 266 y 1382) pueda acumularse cuando las condiciones de uno y otro se cumplan.

52 El artículo 1382 del Code dispone que: "Tout fait quelconque de l'homme, qui cause à autri un dommage, oblige celui par la faute duquel il est arrivé, à le réparer" (cualquier hecho del hombre que dañe a otro, obliga a aquel por cuya culpa éste se produjo, a reparlo). CoDE CIVIL, p. 1669. 
limitación (como sí lo establece el artículo 2059 del Codice civile ${ }^{53}$ ) al resarcimiento del perjuicio. En estos términos, se han admitido las demandas por responsabilidad civil por aplicación de los artículos 1382 y 1383 del Code, que disciplinan la responsabilidad extracontractual y de forma absolutamente coetánea e independiente del divorcio por incumplimiento de los deberes del matrimonio. Bénabent nos señala, a este respecto, que la responsabilidad aquiliana, que emana del artículo 1382 del Code, exige una imputabilidad coetánea o no a la causal de divorcio y que incluso se aplica respecto del divorcio por culpa recíproca, y por consentimiento mutuo. En cambio, el artículo 266 del Code procede sólo respecto del perjuicio que es consecuencia del divorcio, y naturalmente no comprende la prestación compensatoria, es decir, la compensación económica ${ }^{54}$. En todo caso el sistema francés no ha estado exento de críticas por su dualidad de fuentes en materia de indemnización de perjuicios ${ }^{55}$.

En Alemania por aplicación del $\S 823$ del $B G B$ no se ha admitido la indemnización de perjuicios ${ }^{56}$ por incumplimiento de deberes matrimoniales ${ }^{57}$.

53 El artículo 2059 del Code (Danni non patrimoniali) dispone que: "il danno non patrimoniale debe essere risarcito solo nei determinati dalla legge". SCICCHITANo (2012), p. 471.

54 Bénabent (2010), pp. 256-257.

${ }^{55}$ A este respecto Mulon nos señala que "[l]e droit du divorce n'échappe naturellement pas au droit commun de la responsabilité, et notamment à l'article 1382 du Code civil, aux termes duquel quiconque cause à autrui un dommage peut être contraint à le réparer. Pour autant, la réparation du préjudice s'avère, en la matière, moins aisée qu'il n'y paraît, les préjudices résultant d'un divorce pouvant revêtir différentes formes, parfois malaisées à déterminer. En outre, le système dualiste de réparation des préjudices liés au divorce actuellement en vigueur-qui impose que les préjudices liés à la dissolution du lien conjugal soient réparés sur le fondement de l'article 266 du Code civil, et les autres préjudices sur celui de l'article 1382 précité-, génère un contentieux lourd qui conduit à s'interroger sur une simplification du régime d'indemnisation en matière de divorce, et notamment sur l'opportunité de supprimer purement et simplement l'article 266" ([e]l derecho de divorcio no escapa naturalmente al Derecho común de la responsabilidad, y en particular al artículo 1382 del Código Civil, en virtud del cual quién cause a un tercero un daño puede ser obligado a reparar dicho daño. Para esto, la reparación del perjuicio resulta, en la materia, menos fácil por cuanto los daños resultantes de un divorcio pueden revestir distintas formas, a veces difíciles de determinar. Además, el sistema dual de reparar los daños relacionados con el divorcio actualmente en vigencia -que exige que los daños relacionados con la disolución del vínculo conyugal se reparen sobre la base del artículo 266 del Código Civil, y las otras pérdidas, conforme al artículo 1382 antes citado, genera un contencioso pesado que lleva a preguntarse sobre la simplificación del régimen de indemnización del divorcio, y en particular sobre la conveniencia de suprimir pura y simplemente el artículo 266). Mulon (2014), p. 6

${ }^{56}$ En este sentido se ha sostenido que: "[l]a jurisprudencia alemana ha afirmado en repetidas ocasiones que la normativa particular del Derecho de familia excluye cualquier pretensión de naturaleza aquiliana". LóPEZ DE LA CRUZ (2010), p. 17.

57 El § 823 (Schadensersatzpflicht) del BGB dispone que: “(1) Wer vorsätzlich oder fahrlässig das Leben, den Körper, die Gesundheit, die Freiheit, das Eigentum oder ein sonstiges Recht eines anderen widerrechtlich verletzt, ist dem anderen zum Ersatz des daraus entstehenden Schadens verpflichtet. 
Ello se debe a que el sistema de responsabilidad extracontractual alemán es de "numerus clausus"; pero además se ha estimado, acertadamente a nuestro entender, que la indemnización de perjuicios por incumplimiento de deberes establece una pena que afecta al divorcio o lo inhibe ${ }^{58}$. Así, se ha resuelto por una nutrida jurisprudencia que si no procede la indemnización de perjuicios respecto del cónyuge culpable, tampoco procede contra el tercero por la infidelidad de uno de los cónyuges ${ }^{59}$. Sin embargo, recientemente, el Tribunal Supremo alemán ha comenzado a otorgar indemnización de perjuicios por infracción de los deberes familiares ${ }^{60}$. Tampoco es aplicable en la especie, el $\S 826 B G B$, que se refiere a los daños derivados de la infracción a las buenas costumbres $^{61}$. Por su parte, el $\S 1353 B G B^{62}$, se limita a establecer el deber de los cónyuges de vivir juntos, sin disponer ninguna acción indemnizatoria. Así, la jurisprudencia germana se ha abierto a aceptar la aplicación del § 826 BGB en

(2) Die den Schutz eines anderen bezweckendes Gesetz verstößt. Ist nach dem Inhalt des Gesetzes ein Verstoß gegen dieses aunch ohne Verschulden möglich, so tritt die Ersatzpflicht nu rim Falle des Verschuldens ein". SCHulze (2005), p. 999. § 823 (Obligación de indemnizar por daños). (1) Quien, dolosa o negligentemente, de forma antijurídica dañe la vida, el cuerpo, la salud, la libertad, la propiedad u otro derecho de otra persona, está obligado a indemnizarle cualquier daño causado por esto. (2) La misma obligación incumbe a aquel que infrinja una ley que tenga como objeto la protección de otro. $\mathrm{Si}$, de acuerdo con las disposiciones de la ley, la infracción de ésta es posible sin culpa, la obligación de indemnizar sólo aparece en caso de culpa. Airanova (1998), pp. 261-262.

58 AlgarRa es de la opinión que: "[l]a violación de los deberes conyugales tiene como consecuencia la posibilidad de demandar la separación o el divorcio, pero no los posibles daños, porque eso sería contrario a la esencia del matrimonio". AlgarRa (2012), p. 19.

59 Romero (2011), p. 32.

60 ROMERO (2011), p. 68.

${ }^{61}$ La norma de la referencia es del siguiente tenor: "(Sittenwidrige vorsätzliche Schädigung) Wer in einer gegen die guten Sitten vertoßenden Weise einem anderen vorsätzlich Schaden zufügt, ist dem anderen zum Ersatz des schadens verpflichtet". Münchener Kommentar Zum Bürgerlichen Gesetzbuch (2009), p. 2159.

Traducción (EIRANOVA): § 826 del BGB (Daño doloso contrario a las buenas costumbres). Quien dolosamente causa un daño a otra persona de una manera contraria a las buenas costumbres está obligado a indemnizarle por el daño. Eiranova (1998), p. 262.

62 El § 1353 del BGB (Eheliche Lebensgemeinschaft)dispone que: "(1) Die Ehe wird auf Lebenszeit geschlossen die Ehegatten sind einander zur ehelichen Lebensgemeinschaft verpflichtet; sie tragen füreinander Verantwortung. (2) Ein Ehegatte ist nicht verflichtet, dem Verlangen des anderen Ehegatten nach Herstellung der Gemeinschaft Folge zu leisten, wenn sich das Verlangen als Mißbrauch seines Rechtes darstellt oder wenn die Ehe gescheitert ist". MünChener Kommentar Zum Bürgerlichen Gesetzbuch (2000), p. 200.

Traducción (EIRANOVA): § 1353 del BGB (La comunidad conyugal). (1) El matrimonio se contrae de por vida. Los esposos están recíprocamente obligados a vivir en comunidad conyugal. (2) Tras la constitución de lo comunidad conyugal el cónyuge no estará obligado a atender la exigencia del otro en coso de que ésta constituya abuso de su derecho. Lo mismo se aplicará en caso de ruptura matrimonial. EIRANOVA (1998), p. 407. 
el caso de engaño malicioso acerca de la concepción de hijos. Se trata del caso en que una mujer, cometiendo infidelidad, trata de engañar a su marido sobre su paternidad ${ }^{63}$ (sentencia del TS alemán, BGH, de 19 de diciembre de 1989).

En Estados Unidos de América ${ }^{64}$, en principio, no se admitió dicha indemnización en consideración a la teoría de la inmunidad de las relaciones de familia y del matrimonio ${ }^{65}$. Sin embargo, dicha teoría comenzó a descartarse a raíz del caso "Thomson v. Thomson", de 1910. En dicho juicio Jessie Thomson demandó a su cónyuge, Charles, de indemnización de perjuicios por maltrato. A pesar que la Corte desechó la demanda el voto de minoría terminaría por imponerse. El argumento del libelo fue muy simple: si el Derecho permitía que la mujer demandara por defraudar en sus bienes (en la administración del marido), con mayor razón debía permitirlo si se viola su integridad. ${ }^{66}$ En otro caso "Ashford vs Ashford", esta vez de 1974, la Corte Suprema de Arizona admitió una demanda por indemnización de perjuicios de los hijos contra su padre por la muerte de la madre (el marido ingresa temerariamente un auto que conducía a un canal en medio de una tormenta, produciendo la muerte de su mujer y de la mayor parte de su familia). El argumento tradicional para desechar la demanda en estos casos era la unidad de la familia. Una parte no podía demandar a la otra fracción de una misma familia; pero esta vez el principio se dejó de lado por insostenible. Otro tanto sucedió con el argumento de la tranquilidad doméstica. En igual sentido se pronuncia la Corte de lowa, en 1976, en "Coffindaffer vs. Coffindaffer" por las agresiones sufridas por la cónyuge, de parte de su marido, a la espera de una sentencia de divorcio. A su vez, antes de estos fallos, se desecharon demandas entre cónyuges por

${ }_{63}$ Véase Algarra (2012), pp. 19-21.

${ }^{64}$ El matrimonio era considerado como una causal de inmunidad particular respecto de demandas entre cónyuges. Ello era una consecuencia de la forma en que se entendía el matrimonio, como un poder del marido sobre la mujer y un derecho a excluir al resto. Así, por ejemplo, tampoco se admitía una demanda patrimonial de la mujer contra su marido por administración fraudulenta o negligente. Naturalmente, no era posible demandar a la mujer casada, por cuanto era incapaz. EPSTEIN (1999), pp. 613-615.

${ }^{65}$ En este sentido, se rechazó la indemnización de daños en el caso "Zepeda vs. Zepeda", en 1963. La Corte de Illinois decidió no condenar al progenitor de un hijo nacido fuera del matrimonio. El demandante argumentaba que el padre sedujo a la progenitora con falsas promesas de matrimonio, sin embargo, la Corte, si bien reconoce que se daban en la especie los requisitos de un tort, resuelve, en definitiva, que de acogerse la demanda, ello daría lugar a consecuencias sociales indeseables. ROMERO (2009), pp. 16 y 35-37.

${ }^{66}$ Romero Coloma señala que: "[e]n similar sentido se ha manifestado el Derecho en Inglaterra, donde la regla de que no existían daños entre cónyuges fue cayendo en desuso y, finalmente, fue derogada por la Law Reform (Husband and Wife) en 1962, que reconoció a cada cónyuge legitimación para interponer acciones contra el otro como si no hubieran estado casados". ROMERO (2009), p. 36. 
accidentes automovilísticos, que buscaban hacer efectivos los seguros, por supuesto fraude a las compañías aseguradoras. Naturalmente, esta situación sería corregida por la Married Women `s Act por la cual se admitió la demanda por "torts" entre cónyuges. Esta tendencia ya se había impuesto en el $R U$, desde la Law Reform de 1962. Pero, también se proveyeron de mecanismos para evitar la colusión de cónyuges contra las compañías de seguro o sus empleadores. Así, muchos estados distinguen lo cotidiano del matrimonio, como los accidentes domésticos de los riesgos asegurables, aplicando el principio de la inmunidad exclusivamente a la primera situación ${ }^{67}$. Esta diferenciación podría explicarse con relación a la gravedad del acto por cuanto los accidentes domésticos, que ocurren naturalmente por negligencia, no podrían dar lugar a la responsabilidad civil.

\section{IV.2. Violaciones graves al estatuto del matrimonio como presupuesto de la responsabilidad civil}

La jurisprudencia española ha tendido a reconocer la posibilidad de demandar daños y perjuicios ante este supuesto. La expansión del Derecho de daños en materia familiar, se plasma en la sentencia del Tribunal Supremo de 30 de junio de 2009 (RJ/2009/5490), que aplica el artículo 1902 del CCE a fin de reparar el perjuicio sufrido por uno de los padres, por el entorpecimiento de las relaciones paterno-filiales por parte del otro progenitor ${ }^{68}$. Naturalmente las infracciones estatutarias del matrimonio, que a su vez transgreden los derechos fundamentales, son consideradas como supuestos de violación grave. Así, se puede citar la sentencia de 14 de mayo de 2001, que otorga acción resarcitoria, por la lesión de un derecho fundamental ${ }^{69}$. Se puede recurrir, además, a las sentencias de la Audiencia Provincial de Baleares de 14 de septiembre de 2001; Audiencia Provincial de Segovia de 30 de septiembre de 2003; Audiencia Provincial de Valencia de 2 de noviembre de 2004 (confirmada por la sentencia del Tribunal Supremo de 10 de junio de 2008); Audiencia Provincial de Madrid de 10 de julio de 2007; Audiencia Provincial de Murcia de 30 de enero de 2009, entre muchas otras ${ }^{70}$. Cabe destacar que no sólo ante los supuestos de dolo, se acepta la acción indemnizatoria, sino que

\footnotetext{
67 EPSTEIn (1999), pp. 613-614.

68 Véase Algarra (2012), p. 14.

${ }^{69}$ Véase Algarra (2012), p. 39.

70 Algarra (2012), p. 15 y Romero (2008), pp. 47 y ss.
} 
también en caso de "negligencia grave" (sentencia de la Audiencia Provincial de Barcelona de 16 de enero de 2007) ${ }^{71}$.

En contra de la jurisprudencia anterior, la sentencia del Tribunal Supremo de 22 de julio de 1999 (RJ/1999/5721), denegó una acción indemnizatoria, por considerar que la actuación de la mujer (el ocultamiento al marido de la identidad del padre del hijo) no constituye una actuación dolosa, no pudiendo ser posible, por tanto, aplicar el artículo 1902 CCE (igual criterio siguió el Tribunal Supremo, en las sentencias de 14 de julio de 2010 (RJ/2010/5152) y 18 de junio de 2012 (RJ/2012/213465), declarando la prescripción de la acción resarcitoria ${ }^{72}$. En todo caso ambos fallos tienen en común el aceptar que violaciones "graves" al estatuto matrimonial generan responsabilidad civil. Lo que sucede es que el fallo del TS de 1999 no consideró doloso el ocultamiento de la identidad del padre del hijo. Sin embargo, el Tribunal Supremo, a partir de un fallo de 30 de junio de 1999, viene diferenciando el estatuto jurídico del matrimonio del de la responsabilidad civil. A este respecto, Roca I Trías concluye que "[e]n cambio, el argumento de la segunda sentencia se ajusta plenamente a lo que se ha venido insistiendo en este trabajo, dado que el Tribunal Supremo separa claramente determinados incumplimientos de los deberes del matrimonio, a los que considera como causas de separación, de la indemnización. Nos hallamos ante lo que había venido aplicándose en nuestro Derecho matrimonial desde el inicio de su regulación con la Ley de Matrimonio civil de 1870, y que hemos visto aceptan también los juristas anglosajones: el incumplimiento del deber de fidelidad, en el caso de la sentencia, no constituye un supuesto de responsabilidad (contractual según el recurso de casación), sino únicamente causa de separación" ${ }^{\prime 73}$.

En Francia, la referencia a la violación estatutaria grave está consagrada expresamente en el artículo 266 del Code, modificado por la Ley No 2004-439, de 26 de mayo de 2005. Así, la norma precedente establece que: "[s] in prejuicio de la aplicación del artículo 270, se podrá conceder una indemnización por daños y perjuicios a uno de los cónyuges para reparar las consecuencias de especial gravedad que sufra por el hecho de la disolución del matrimonio, ya sea cuando haya sido demandado en un divorcio pronunciado por alteración definitiva del vínculo matrimonial y sin que hubiese él mismo interpuesto demanda alguna de divorcio, ya sea cuando el divorcio fuese pronunciado

71 BarCeló (2012), pp. 79-128.

72 Barceló (2012), pp. 30 y 32.

73 Roca I Trías (2000), p. 561. Asimismo, Vargas (2009), p. 149. 
por culpa exclusiva de su cónyuge. Esta petición sólo podrá formularse en el procedimiento de divorcio" ${ }^{14-75}$. La regla del artículo precedente es exigente en la determinación de la responsabilidad civil. Así lo ha entendido la Corte

${ }^{74}$ La norma de la referencia es del siguiente tenor: "[s]ans préjudice de l'application de l'article 270, des dommages et intérêts peuvent être accordés à un époux en réparation des conséquences d'une particulière gravité qu'il subit du fait de la dissolution du mariage soit lorsqu'il était défendeur à un divorce prononcé pour altération définitive du lien conjugal et qu'il n'avait lui-même formé aucune demande en divorce, soit lorsque le divorce est prononcé aux torts exclusifs de son conjoint. Cette demande ne peut être formée qu'à l'occasion de l'action en divorce". Code Civil (2012), p. 419.

75 Terre y Fenouillet se refieren a la evolución de esta norma. Para ello abordan la Reforma de 1975, caracterizada por un rechazo del divorcio culpable y por el establecimiento de la compensación económica, se encuentra al origen del actual art. 266 del Code. Sin embargo, la jurisprudencia francesa tempranamente había reconocido la posibilidad de demandar por la vía de la responsabilidad extracontractual frente a incumplimiento de deberes del matrimonio que fuesen graves. Por la indemnización, a que hacía referencia la Reforma de 1975 respecto del artículo 266 del Code, se podía condenar al cónyuge culpable del divorcio a la reparación del daño material o moral que había sufrido el otro contrayente. Esta acción se daba dentro del divorcio y necesariamente comprendía los perjuicios que el divorcio generaba al cónyuge inocente. Naturalmente, se trataba de una acción de perjuicios por el daño reparable que no tenía que ver ni con la capacidad económica de los cónyuges, ni con las necesidades del cónyuge inocente. TerRe y FenOuILlet señalan que la jurisprudencia había rechazado esta acción invocando la pena que generaba el término de una larga vida en común, aún cuando daba lugar a ella en casos graves. Así se resolvió conceder la indemnización cuando un cónyuge, sufriendo la expulsión del hogar común, debió soportar las infidelidades del otro cónyuge.

En este sentido, los referidos autores señalan que "[e]n raison du divorce, il est dans certaines conditions possible d'obtenir des dommages-intérêts en raison du droit commun de la responsabilité civile en application des articles 1382 et 1383 du code civil: violences, atteintes à la dignité, etc. Mais, signe d'un temps ou le divorce pour faute régnait sans partage, il était prévu, dans le droit antérieur à la reforme de 1975, qu“ «indépendamment de toute autre réparation due par l'époux contre lequel le divorce a été prononcé, les juges pourront allouer au conjoint qui a obtenu le divorce des dommages-intérêts pour le préjudice matériel ou moral à lui causé par la dissolution du mariage» (anc. art. 301, al. 2, c. civ). Le caractère indemnitaire de ces dommages-intérêts était attesté par le fait qu'ils ont été accordés même à l'époux disposant de ressources suffisantes" ([e]n razón del divorcio, bajo ciertas condiciones es posible obtener indemnización de perjuicios sustentado en el derecho común de la responsabilidad civil de conformidad con los artículos 1382 y 1383 del Código Civil, por violencia, atentados a la dignidad, etc. Sin embargo, signo de una época donde el divorcio culpable reinaba sin contrapeso, se preveía, en el derecho anterior a la reforma de 1975, que "independientemente a cualquiera otra reparación debida por el cónyuge contra quien se pronunciaba el divorcio, los jueces podían otorgar al cónyuge que había obtenido el divorcio indemnización de perjuicios por el daño material o moral que le hubiese causado la disolución del matrimonio" (antiguo art. 301, inciso $2^{\circ}$ c. civ). El carácter reparatorio de esta indemnización de perjuicios estaba expresado por el hecho que ella era acordada incluso al cónyuge que disponía de recursos suficientes.

La reforma de 1975 modificaría el artículo 266 del Code, disponiendo que "Quand le divorce est prononcé aux torts exclusifs de l'un des époux, celui-ci peut être condamné a des dommages-intérêts en réparation du préjudice matériel ou moral que la dissolution du mariage fait subir a son conjoint. Ce dernier ne peut demander des dommages-intérêts qu'à l'occasion de l'action en divorce" (cuando el divorcio haya sido pronunciado por culpa exclusiva de uno de los cónyuges, éste podrá ser condenado a una indemnización de perjuicios para reparar el daño material o moral que por la disolución del matrimonio sufre su cónyuge. Este último no podrá reclamar daños y perjuicios que sean consecuencia de la acción de divorcio). TeRre y Fenouillet (2005), pp. 479-480. 
de Casación, mediante un fallo de 6 de julio del $2005^{76}$, doctrina que se ha seguido aplicando por el mismo alto tribunal francés en fallos posteriores ${ }^{77}$. En Italia, una sentencia de casación civil, de 10 de mayo del 2005, admitió una indemnización de perjuicios por nulidad de matrimonio ${ }^{78}$, cobijada en el art. 2059 del Codice civile, y concretamente en la reparación de los daños sufridos por la violación de los derechos fundamentales ${ }^{79}$. La nulidad procedió

${ }^{76}$ En un caso donde la sentencia de divorcio es pronunciada por culpa de ambos cónyuges, la Corte de Casación casa y anula una sentencia de la Corte de París que había dejado entrever que la declaración de divorcio constituía en sí misma la reparación de un perjuicio. La Corte de Casación fija la doctrina por la cual establece que para rechazar una demanda de indemnización de perjuicios fundada en el art. 1382 los jueces del fondo deben constatar la ausencia de un perjuicio distinto al causado por la disolución del matrimonio. En concreto, para la indemnización de los daños resultantes de la disolución del matrimonio se aplica el art. 266 mientras que para reparar un perjuicio distinto, la disciplina del art. 1382 es la que debe aplicarse. Así resuelve la sentencia del alto tribunal: "[v]u les articles 266 et 1382 du Code civil; Attendu que le prononcé du n'a pas pour objet la réparation d'un préjudice, que les dommagesintérêts prévus par l'article 266 du Code civil réparent le préjudice causé par la rupture du lien conjugal tandis que ceux prévus par l'article 1382 du même Code, réparent le préjudice résultant de toute autre circonstance ; Attendu que pour débouter Mme Le Y de sa demande de dommages-intérêts fondée sur l'article 1382 du code civil, la cour d'appel énonce que celle-ci n'établit pas l'existence d'un préjudice matériel et moral distinct de celui réparé par l'accueil de sa demande en divorce; Qu'en statuant ainsi, la cour d'appel a violé les textes susvisés. Par ces motifs: CASSE ET ANNULE, mais seulement en ce qu'il a rejeté la demande de dommages-intérêts de Mme Le Y., I'arrêt rendu entre les parties par la cour d'appel de Paris" (Vistos, los artículos 266 y 1382 del Código civil; Considerando que la sentencia de divorcio no tiene por objeto la reparación de un daño; que las indemnizaciones de perjuicios previstas en el Art. 266 del Código civil reparan el daño causado por la ruptura del matrimonio mientras que las previstos por el artículo 1382 del mismo Código, reparan un daño resultante de otra circunstancia; Considerando que para rechazar la demanda de indemnización de perjuicios de la Sra. Le Y. fundada en el artículo 1382 del Código Civil, la Corte [de apelaciones] señala que ésta no establece la existencia de un daño material o moral distinto de aquel ya reparado al acogerse su demanda de divorcio; Que, al resolver así la Corte de Apelaciones ha violado los textos antes mencionados. Por estos motivos: casa y anula, pero sólo en la parte que rechaza la demandad de indemnización de perjuicios de la Sra. Le Y., la sentencia dictada entre las partes por la Corte de apelaciones de París). Ver: L'essentiel de la Jurisprudencie civile. Famille, Gualino, 2e édition, París, Francia, p. 98.

77 V. Sentencia de la primera sala civil de 23.01.2007 y sentencia de la misma sala de 5 de noviembre de 2008.En otro fallo de la $1^{\text {a }}$ Sala civil de la Corte de Casación, de $1^{\circ}$ de julio de 2009 ( $\mathrm{N}^{\circ}$ 08-17.825, Bull. civ. I, No 145; D. 2009. 1897, obs. C. Le Douaron), una Corte de Apelaciones admite la aplicación del art. 266 del Code en el caso de un marido que después de 39 años de matrimonio deja a su mujer en condiciones difíciles para buscar una nueva compañía. La Corte de casación, sin embargo, censura esta decisión estimando que estos motivos son insuficientes para caracterizar "las consecuencias de particular gravedad", que exige el art. 266. La Corte de Apelaciones había justificado la aplicación del art. 266 por la actitud del marido y no por las consecuencias dañosas de la separación. La misma doctrina sigue una sentencia de la misma sala civil de 18 de enero de 2012 (Civ. 1 re, 18 janv. 2012, $\left.\mathrm{N}^{\circ} 11-10.959\right)$ y 6 de marzo de 2013 ( No 12.12.338).

${ }^{78}$ En este sentido, Algarra Prats señala que: "[Esta sentencia] tiene una importancia decisiva en todo el proceso que ha llevado a la actual situación en el Derecho italiano, pues hasta ese momento, la Corte de Casación no se había pronunciado de modo claro sobre la aplicabilidad del art. 2043 C.c. italiano en caso de violación de los deberes conyugales". Algarra (2012), pp. 24-25.

${ }^{79}$ Confróntese: Algarra (2012), p. 25. 
por no haber declarado el esposo su impotencia ${ }^{80}$. La tendencia a admitir la indemnización de perjuicios respecto de incumplimiento grave de deberes matrimoniales se había iniciado en 1975, con una sentencia de 19 de junio de la Corte de Casación Civil. Dicho fallo acogió una acción indemnizatoria por infracción del deber conyugal de fidelidad ${ }^{81}$. En este sentido, Fraccon se declara a favor de la indemnización de daños y perjuicios por infracción de los derechos-deberes en materia familiar ${ }^{82}$, sobre la base de una interpretación extensiva del artículo 2043 del Codice civile ${ }^{83}$. Se dice que esta norma "[t]iene un marcado carácter de atipicidad, lo que permite su aplicación a favor de cualesquiera intereses merecedores de protección" ${ }^{\prime 84}$. Ésta ha sido la posición mayoritaria de la doctrina, aunque naturalmente no es unánime. De Verda Y Beamonte se opone a estas tesis, en un comentario a la sentencia de 4 de junio de 2002, dictada por el Tribunal de Milán. El caso se funda en una demanda presentada por la mujer en contra de su marido, por cuanto después de ser novios por siete años, a los dos años de casados la mujer queda embarazada, lo que significó un cambio radical en la conducta del marido, quien, al final, le fue infiel, acogiéndose la demanda indemnizatoria, por los daños afectivos, morales y materiales en contra de la demandante y su hijo ${ }^{85}$. La jurisprudencia italiana ha tenido, en el último tiempo, una posición más restrictiva, alentada,

${ }^{80}$ Confróntese: VARGAS (2009), p. 134.

81 En Italia, se ha discutido la posible indemnización de daños, a propósito de las siguientes materias: la violazione del dovere di fedeltà (Cass. 18 settembre 1997, № 9287; Cass. 30 gennaio 1992, № 961; Cass. 7 setttembre 1999, № 9472; Trib. Brescia 14 ottobre 2006); la violazione degli obblighi di mantenimento (Cass. 17 settembre iugno 1996, № 8305; Cass. 2 marzo 1994, № 2038; Cass. 7 giugno 2000, $\mathrm{N}^{\circ}$ 7713); la lesione del rapporto genitoriale (Trib. Roma 13 giugno 2000, DFP, 2002; App. Bologna 10 febbraio 2004, FD, 2006); la condotte violente in famiglia (Cass. 2 settembre 2005, № 17710); la responsabilità aggravata per lite temeraria (Trib. Bologna 20 settembre 2005, № 2418); la seduzione con promessa di matrimonio (Cass. 10 giugno 1948, No 1434; Cass. 10 agosto 199, № 8733; Cass. 8 luglio 1993, № 7493; Cass. 27 novembre 1986, № 6994). Confróntese: Sella (2011), pp. 235-252.

82 En este sentido, la Sentencia de Casación de 31 de mayo de 2003, № 8828, destaca la protección del interés de carácter constitucional, que no tiene un carácter puramente económico, cuya lesión sí se encuentra protegida por lo dispuesto en el artículo 2043 del CC, con la limitación contenida en el artículo 2059 respecto del daño. Confróntese: SelLA (2010), p. 557.

${ }^{83}$ El artículo 2043 (Risarcimento per fatto illecito) del Codice civile dispone que: "[c]ualquier acto malicioso o negligente, que causa daño a otra persona, obliga al agente que cometió el acto a pagar daños y perjuicios". Confróntese: Dı MAjo (2012), p. 506. Al respecto, vid.: Cass., 1 ottobre 1994, n. 7989; Cass., 27 luglio 1998, n. 7357; Cass., sez. Lav., 29 settembre 1998, n. 9734; Cass., 27 luglio 1998, n. 7337; Cass., 27 giugno 1989, 3117, in Foro pad., 1990, I, 271; Cass., 26 giugno 1995, n. 7231; Cass., 17 maggio 1997, n. 4426. Confróntese: Galgano (2001), pp. 1302-1303; BuonCristiano (1997), pp. 2308 y ss.

${ }^{84}$ Algarra (2012), p. 24.

${ }^{85}$ Confróntese: Romero (2011), pp. 18-20. 
quizás, por la complejidad que tienen los asuntos familiares ${ }^{86}$. Así, la Sentencia de Casación de 27 de noviembre de 2003 confirma el fallo en cuya virtud se descarta la solicitud de separación de los cónyuges, por cuanto existe una enorme dificultad para determinar la causa que motivó el fracaso de la unión matrimonial, ello debido a la falta de relaciones íntimas, situación tolerada por el cónyuge del solicitante ${ }^{187}$. Cabe hacer presente en este punto, la limitación al resarcimiento del daño moral, que dispone el artículo 2059 del Codice civile ${ }^{88}$. La referida norma al establecer que sólo deben ser indemnizados, los supuestos de daño moral, expresamente previstos en la ley, ha servido en algunos casos como limitación y en otros como amparo a la acción indemnizatoria ${ }^{89}$. Esta es además la tendencia que se ha impuesto en el Código civil suizo (art. 151), y que se está imponiendo en Argentina. Ortiz de Rozas, admitiendo esta posibilidad en el Derecho argentino, destaca varios fallos posteriores a 1997, "[...] en los que se resolvió que el comportamiento merecedor de la sanción por daño moral no está dada por la sola configuración de alguna causal de divorcio (en el caso se trataba de injurias y adulterio durante la separación de hecho), sino por 'el obrar malicioso, de clara y excluyente inspiración nociva hacia el otro cónyuge ${ }^{\prime \prime \prime 90}$. En igual sentido el Proyecto de Código Civil argentino de 1999 admitía esta posibilidad en la medida que concurrieran los siguientes requisitos:

a) Se haya dado lugar a un divorcio culpable de forma exclusiva por el demandado.

b) Que la indemnización se plantee en el proceso de separación.

c) Que haya habido responsabilidad del otro cónyuge que debe haber obrado con dolo o culpa grave ${ }^{91}$.

En los países del "common law" se admite la indemnización de perjuicios por incumplimiento de los deberes del matrimonio, si ha habido dolo, como

\footnotetext{
${ }^{86}$ Confróntese: SeSta (2012), p. 413.

87 Sella (2011), p. 236.

${ }^{88}$ Y sobre todo la interpretación restrictiva de la misma. Confróntese: TRABUCCHI (2009), p. 2195. Confróntese: Alpa (1995), p. 446; Franzoni (1993), pp. 1155 y ss.; Ziviz (1991), pp. 2176-2177.

89 En este sentido, Buoncristiano; Cirillo; Cuffaro y Roselu, plantean que es claro que el artículo 2059 del CC, limita la indemnización por concepto de daño moral, salvo las excepciones que establece: el caso penalmente relevante, los casos en que se emplean expresiones insultantes dentro de un proceso y la responsabilidad del Estado por el daño moral resultante de una privación de libertad. Confróntese: Buoncristiano; Cirillo; Cuffaro y Roselli (1997), p. 2371.

90 Ortiz de Rozas (2001), p. 180.

91 En este sentido, MeDina señala que: “[En el Derecho de Familia] el factor de atribución sigue siendo la culpa o el dolo, y más precisamente de la culpa grave que, si bien no fue admitida en términos generales en el Código Civil argentino, sí lo fue en el de Derecho de Familia". Medina (2008), p. 24.
} 
en los casos de padres engañados respecto de su paternidad (tanto fuera como en el matrimonio $)^{92}$.

\section{Solución al dilema de la responsabilidad civil por incumplimiento de deberes en el Derecho chileno}

Estimamos que se puede dar lugar a la responsabilidad civil, por incumplimiento de deberes del matrimonio, en la medida que el ilícito es de una entidad relevante para el Derecho en general ${ }^{93}$. Como hemos visto en el Derecho comparado, varios autores se inclinan por una aplicación restrictiva de la indemnización por incumplimiento de deberes del matrimonio, e incluso sostienen el rechazo de la indemnización de perjuicios por infidelidad, como Albaladejo, Roca I Trias y Romero Coloma ${ }^{94}$. Como es natural, y ya se ha analizado, otros autores como Lacruz, están contra la aplicación del principio de especialidad como criterio excluyente de la responsabilidad por incumplimiento a los deberes del matrimonio ${ }^{95}$. No estamos a favor de ninguno de los dos grupos precedentes, sino más bien nos inclinamos por una solución ecléctica. En consideración a ella estimamos que la sola transgresión al estatuto jurídico del matrimonio no lleva aparejada la responsabilidad civil; pero existen supuestos en los que dicha transgresión, unida a otras consideraciones, puede llevar a dicha responsabilidad ${ }^{96}$. No estimados, como ha señalado parte importante de nuestra doctrina, que proceda la indemnización de perjuicios por incumplimiento de deberes matrimoniales "per se" o como corolario necesario de la declaración de un cónyuge como culpable o por el no pago de los alimentos. Así, no estamos de acuerdo con los criterios planteados por autores como Javier Barrientos. El referido profesor se pregunta si procede la indemnización de perjuicios por

\footnotetext{
92 A este respecto, CRETNEy y FLEMING, citados por Roca I Trías, se refieren a la acción indemnizatoria que tiene el marido por la privación de los servicios de la mujer, por actos imputables a terceras personas. Roca I Trías (2000), pp. 558-559.

${ }_{93}$ En este sentido, Corral expresa que: "[u]na adaptación de la responsabilidad a las relaciones familiares podría fundarse con mayor plausibilidad en los textos normativos actuales en sede de justificación del daño y no en el grado de culpa del autor de la ofensa (como en algunas partes de la monografía se insinúa, pero se desarrolla). En general, sostenemos que no todo daño debe ser reparado por medio de la responsabilidad civil sino aquellos que son significativos porque sobrepasan un umbral mínimo de tolerancia". CORRAL (2009), pp. 180-181.

94 Véase, VArGas (2009), p. 148.

95 VARGaS (2009), p. 151.

${ }^{96}$ En este punto, AlGARRA expresa lo siguiente: "[e]n definitiva, la responsabilidad aquiliana presupone que la lesión se refiera a derechos de la persona no creados por el vínculo matrimonial, porque lo que se protege con la responsabilidad civil no son aquellos valores que el matrimonio ha constituido ex novo para los cónyuges, como el deber de fidelidad; la violación de este deber no produce necesariamente la obligación de resarcir ningún daño si no se han lesionado otros valores que haya que proteger". Algarra (2012), pp. 26-27.
} 
incumplimiento del deber de vivir en el hogar común por parte de uno de los cónyuges. Ante lo cual el gran historiador del Derecho razona de la siguiente forma: "...¿Solicitar indemnización de perjuicios?: sí el incumplimiento de la obligación de vivir en el hogar conyugal se debe a un acto imputable a malicia o negligencia de uno de los cónyuges y tal acto genera un daño en el otro, nada parece que obstaría a que, sin necesidad de solicitar la separación judicial o la declaración de divorcio, el cónyuge afectado demandara la reparación de tales daños, sobre la base de la regla general sentada en el artículo 2329 del Código Civil" $^{\prime 97}$. Nos inclinamos a favor de autores, como Segura, que exigen un alto grado de imputabilidad para que proceda la indemnización de perjuicios ${ }^{98}$. Severín es de la idea que en esta materia estamos frente a un vacío regulatorio - por cuanto a diferencia de otros países no hay una norma que establezca directamente la responsabilidad por incumplimiento grave de deberes conyugales, como la francesa- que se debe llenar ponderando dos principios: uno general del derecho: todo daño debe ser reparado y otro específico del Derecho de Familia: la unidad y protección de la familia, que lleva a que sea esta rama del Derecho la que regule las relaciones de familia99.

Esta posición es la sostenida por parte de la doctrina española ${ }^{100}$, y también en cierta medida por la francesa, como ya se ha analizado.

En definitiva, de la precedente argumentación y de lo hasta aquí analizado del Derecho comparado, es dable concluir que la responsabilidad por incumplimiento de deberes del matrimonio sólo procede como una causal calificada de ilicitud, o agravada de imputabilidad, como sucede en los siguientes supuestos:

\section{V.1. Calificación del ilícito como penal}

Existe un cierto consenso en el Derecho comparado en que la infracción estatutaria de los deberes del matrimonio que constituye un ilícito penal genera indemnización de perjuicios ${ }^{101}$. Así, Vargas señala que un buen número de autores, que niegan la indemnización de perjuicios por daño moral, por incumplimiento de deberes del matrimonio, la admite en materia de responsabilidad penal. A este respecto se cita a Roca I Trias ${ }^{102}$, Ferrer Riba y Rodríguez Gutián ${ }^{103}$. En Chile, Severín parece adherir a esta posición cuando señala que se debe

\footnotetext{
97 Barrientos (2011), p. 563.

98 Segura (2003), p. 124.

99 Severín (2008), pp. 113-114 y 129-140.

100 RodríGuez (2003), pp. 65 y ss.

101 Véase De Verda y Beamonte (2012), pp. 161 y ss.

102 Roca I Trías (2000), pp. 552 y ss.

103 Véase VARGaS (2009), pp. 180-184.
} 
"[d]ejar abierta la posibilidad de obtener una reparación de los casos en que ha existido algún tipo de violencia intrafamiliar, a la vez que la cerramos, por ejemplo, para el adulterio, el alcoholismo, la conducta homosexual, etc.", es decir, los casos en que hay un delito penal, como eventualmente puede suceder en la violencia intrafamiliar, generan acción reparatoria y los casos de incumplimiento de deberes del matrimonio quedarían excluidos ${ }^{104}$.

Estos casos no son más que la aplicación de las reglas generales de la responsabilidad civil. De este modo es indudable que la responsabilidad penal, tanto por delito como de cuasidelito penal, da lugar a casos de ilícitos civiles agravados, como el manejo descuidado de un cónyuge que produce la lesión o la muerte del otro, la violación de los hijos, maltrato físico o psicológico al otro cónyuge o a los hijos, la suplantación de identidad, acompañada de secuestro de menores, etc. A favor de esta posición se puede señalar que el estándar de la prueba en el Derecho Penal es mucho más exigente que en el proceso civil. Así, por ejemplo, en algunos ordenamientos jurídicos, la responsabilidad civil es un mecanismo de distribución o de prevención de riesgo. Pero, el Derecho Penal se inclina a favor de la presunción de inocencia en un sentido radical, por cuanto la sanción penal conlleva la restricción de los derechos humanos del transgresor. Por ello, el Derecho Penal, en el Derecho moderno, cumple una tímida función preventiva, que en la actualidad tiende a suplir el Derecho Privado $^{105}$. Esta función preventiva podría cumplirse eventualmente respecto del incumplimiento de los deberes del matrimonio, pero de forma restrictiva a los ilícitos penales.

Sin perjuicio de lo ya señalado, a los casos anteriores se suman casos dudosos, que se presentan sobre todo en los cuasidelitos penales y civiles, como el envenenamiento culposo de un cónyuge a otro, que es alérgico y que produce su muerte o graves consecuencias, las injurias entre cónyuges, etc. Estas conductas si bien transgredirían los deberes recíprocos de cuidado y respeto, que se deben los cónyuges, es dudoso que necesariamente deban generar una indemnización de perjuicios. En consideración a estos casos la responsabilidad civil no puede ser una consecuencia automática de la responsabilidad penal, por cuanto habrá que analizar la gravedad del ilícito, uniéndolo a un criterio de imputabilidad a título de culpa grave o dolo, propio del Derecho civil y no del Derecho Penal. De lo que no cabe duda es que de haber responsabilidad penal estamos en presencia de supuestos que potencialmente pueden dar lugar a la responsabilidad civil entre cónyuges ${ }^{106}$.

104 Severín (2008), pp. 139-140.

105 Véase Barceló (2012), pp. 88 y ss.

${ }^{106}$ El autor recién citado señala que: "[...] la discusión está entre quienes sostienen que se responde únicamente por dolo (o culpa grave) y quienes, en cambio, estiman que se satisface el requisito de la 
En resumidas cuentas una infracción estatutaria de los deberes del matrimonio que genere responsabilidad penal potencialmente puede dar lugar a la responsabilidad civil. El factor determinante de la responsabilidad civil, será como se analiza más adelante, la agravación del ilícito infraccional.

\section{V.2. Agravación del ilícito infraccional}

La agravación del ilícito infraccional puede estar inmerso en la responsabilidad penal, o ser independiente de ella. Así, puede ser que a pesar de no haber responsabilidad penal, la infracción estatutaria sea de una magnitud que conlleve aparejada la responsabilidad civil.

En este estadio de nuestro análisis, debemos replantearnos la función de la responsabilidad extracontractual por cuanto no es posible seguir la tesis que sostiene que la responsabilidad extracontractual se rige por el principio del resarcimiento integral del daño. El Derecho civil moderno está llamado a cumplir una función disuasiva ante la retirada del Derecho penal. Ello se debe, como hemos podido apreciar, a que el Derecho penal, en un Estado de Derecho, ha cedido su función preventiva en pos del debido proceso y la presunción de inocencia.

El entender que el Derecho Civil tiene una función preventiva nos Ileva a preguntarnos en qué consiste dicha función en el Derecho de Familia. Sólo el plantearnos la pregunta nos da luces sobre el problema que estamos analizando por cuanto coincidimos con la visión clásica de los autores chilenos de desechar la aplicación automática del Derecho de Daños al incumplimiento de deberes matrimoniales. Dicho esto nos inclinamos a favor de la aplicación del Derecho de Daños a los referidos incumplimientos, pero en caso que estemos en presencia de ilícitos civiles, no penales, agravados. Estos ilícitos penales agravados se sustentan en consideraciones ajenas o complementarias al incumplimiento de los deberes matrimoniales.

\section{V.3. Casos específicos de ilícitos infraccionales agravados: violación de derechos fundamentales}

Naturalmente que el principio de especialidad como un límite a la responsabilidad civil por incumplimiento de deberes extrapatrimoniales -que es uno de los argumentos más fuertes contra la aplicación de la responsabilidad objeto del presente trabajo- cede ante la violación de derechos fundamentales. Es más el matrimonio, por estar inmerso en el Derecho de Familia e Infancia se construye

intervención de culpa o negligencia contenido en el art. 1902 C.c. tanto si el acto ilícito es imputable al sujeto que lo realiza a título de dolo como si lo es a título de culpa". Barceló (2012), pp. 86-87. 
sobre los derechos fundamentales ${ }^{107}$. Pero precisamente a raíz de ello es que la diferenciación entre Derecho y moral, que se traduce en el principio de la intervención mínima del Estado, es tan relevante.

Por ello es que reiteramos que la regla general es que la infracción a los deberes del matrimonio no genere por sí sola responsabilidad civil $^{108}$; pero dicha responsabilidad debe proceder en los casos en que concurran causas calificadas de violación de derechos fundamentales, es decir, por incumplimiento de deberes del matrimonio ${ }^{109}$, como podría ser a trasgresión a la dignidad de uno de los esposos o cónyuges. En este sentido se ha pronunciado una parte importante de la doctrina española. Para ello se ha recurrido a la calificación del grado de imputabilidad, requiriéndose además de la lesión a un derecho fundamental que esta sea intrínsecamente dolosa y grave ${ }^{110}$. Un ejemplo de la agravación, en el comportamiento del cónyuge, se aprecia en la sentencia del Tribunal de Florencia, de 13 de junio del 2000, por el cual el marido no asistió a su mujer que padecía una esquizofrenia paranoide. Ello se debió, conjuntamente con otras circunstancias -la mujer pasó encerrada durante cuatro años en un cuarto en condiciones de degradación física y psíquica-, al hecho de no recibir a su cónyuge en su hogar una vez que estaba recuperada, desechando las instrucciones médicas que aconsejaban hacerlo. Esta excepción también la considera, Fraccon y Marín -citados por Vargas-que señalan que el incumplimiento a los deberes del matrimonio debe ser intrínsecamente grave o reiterado ${ }^{111}$.

Fuera de los casos analizados es difícil aceptar que la simple calificación de un cónyuge como culpable pueda dar lugar a la indemnización de perjuicios. Un argumento fuerte contra dicha posibilidad es la forma en que se ha regulado en nuestro Derecho la compensación económica. La compensación económica en Chile, a diferencia del Derecho Francés, está íntimamente ligada a la calificación de culpabilidad de uno de los cónyuges respecto de la ruptura. Esta calificación no tiene que ver con la culpa, como un supuesto de imputabilidad en la responsabilidad, sino como una de las circunstancias que llevan

${ }^{107}$ Como señala VARGAS, esta posición, por la cual procede indemnización de perjuicios por infracción de deberes del matrimonio, que, a su vez, constituye tutela de derechos fundamentales, es generalizada en Italia. A este respecto se cita a BONA, De Verda y Marín.

108 En virtud de lo anterior en los países que se ha aceptado la indemnización de perjuicios por incumplimiento de deberes vía jurisprudencial, como en Argentina, no se ha aceptado por las consecuencias del divorcio en sí mismas OrTiz de RozAs (2001), p. 185.

109 Así se ha estimado en España, ya sea por infracción a los derechos de igualdad, libertad, honor, intimidad e incluso solidaridad. LÓPEZ DE LA CRUZ (2010), pp. 32-34.

110 En España, se ha dicho que: "[l]a exigencia de dolo (o de una conducta gravemente negligente) juega, además, un papel importante al surgir como límite de la extensión de la figura de la responsabilidad civil a las relaciones familiares [...]". BARCELó (2012), p. 87.

111 Véase Vargas (2009), p. 189. 
al juez a fijar el "quantum" de la compensación económica. Sin embargo y a pesar de existir norma expresa, la jurisprudencia no ha considerado los criterios de imputabilidad como criterios en la determinación del "quantum", lo que constituye un argumento fuerte a favor de los que desechan la indemnización de perjuicios en el divorcio.

\section{La culpabilidad como criterio de determinación del "Quantum" en la compensación económica}

La incidencia de la culpabilidad o los criterios de imputabilidad en la compensación económica no han sido suficientemente estudiados por nuestra dogmática civil. Sólo al plantearse la discusión, en torno a la naturaleza de la compensación económica, la doctrina hace alguna una referencia a una eventual función punitiva o sancionadora de esta figura que se manifestaría en el artículo 61 de la $L M C^{12}$. Así, la doctrina chilena se ha referido a la indemnización de perjuicios en la compensación económica en torno a la naturaleza de dicha figura. En un comienzo la mayoría de la doctrina civil se inclinó a favor de las tesis resarcitorias; pero esta posición que fue mayoritaria en la doctrina civil ha sido revisada ${ }^{113}$, tanto por la doctrina como por los tribunales, desechándose del todo ${ }^{114}$. El análisis que se realiza a continuación se aleja de estas posiciones por cuanto se centra en la determinación del "quantum", regulado en el artículo

\footnotetext{
112 Barcia y Riveros (2011), pp. 270-271.

113 Autores como VIDAL y PIZARro se adscribieron tempranamente a ella con diversos sustentos; pero posteriormente mantuvieron otras posiciones. PIZARRO (2004), pp. 88 y 89; VIDAL (2004), pp. 280 y 281 y PIZARRO y VIDAL (2009), pp. 31 y 89. Esta doctrina sería revisada por BARRIENTOS que entendía que la categoría de derechos patrimoniales -es decir, de derechos personales y reales- no era aplicable a la compensación económica; por CÉSPEDES y VARGAS, que sostuvieron que la compensación económica, a pesar que da lugar a una obligación legal de contenido patrimonial, se sustenta en la equidad, y tiene por finalidad entregarle herramientas al cónyuge más débil para que pueda reiniciar dignamente su vida separada; y, por BARCIA y RIVEROS que señalaron que esta figura era de naturaleza extrapatrimonial, no resarcitoria, aunque eventualmente genere dicho efecto. BARRIENTOS (2007), p. 17; CÉSPEDES y VARGAS (2008), pp. 450-454 y BARCIA Y Riveros (2011a), pp. 262-263.

114 El rechazo a relacionar la compensación económica con la indemnización de perjuicios, a lo menos en torno a la naturaleza de la institución, o sea respecto de la aplicación del artículo 61 de la LMC, se puede apreciar de forma sumamente clara en el fallo de la CA de Santiago de 4 de noviembre del 2010, Rol Ingreso de la Corte № 890-2010. Dicha sentencia, en su considerando 5º, resuelve: "[q]ue, en realidad, de la demanda se trasunta la idea de la actora de verse indemnizada por los malos tratos que recibió durante la convivencia por parte de su marido. Debe consignarse, en todo caso, que dicha violencia está demostrada en estos autos, desde que se acogió la acción de divorcio por culpa, sin que el demandado se haya alzado en contra de esta decisión. Empero, no es la compensación económica una institución creada para reparar este tipo de perjuicio y puede la actora, si así lo estima, perseguir la responsabilidad del demandado de acuerdo a las normas generales del Código Civil, en la sede y de acuerdo al procedimiento correspondientes, pero lo que no puede pretender es que el supuesto perjuicio que le habrían irrogado los malos tratos del demandado le sean indemnizados por la vía del artículo 61 de la Ley de Matrimonio Civil". La sentencia no es decisiva en torno al rol que juega la
} 
62 de la $L M C$, y no en la determinación de las condiciones que se exigen para la procedencia de la compensación económica en el artículo 61 de la LMC.

La mala fe de los cónyuges, respecto de la nulidad o el divorcio, conforme al artículo $62.1^{\circ}$ de la $L M C$, no sólo sirve para determinar el quantum (aumentándolo o reduciéndolo), sino también para excluir la compensación económica (artículo $62.2^{\circ}$ de la $L M C$ ).

La mala fe, que impediría, reduciría o ampliaría la compensación económica, dice relación con el conocimiento de la causal de nulidad de matrimonio, que puede haber tenido tanto el cónyuge beneficiado, como el deudor ${ }^{115}$. Naturalmente este supuesto puede ser asimilado a una violación contractual de la buena fe. Es verdad que el matrimonio es más que un contrato, pero dicha figura se asimila a un contrato a lo menos respecto de su constitución como sostienen las posiciones funcionalistas del matrimonio ${ }^{116}$. En el divorcio, en cambio, se puede entender que la mala fe dice relación con la mayor o menor culpabilidad que pudo haber tenido el cónyuge beneficiario en la ruptura. En este supuesto la mala fe jugaría como una causal de reducción o ampliación del "quantum" o, incluso, como una causal de extinción de la compensación económica. Esta materia está regulada en la $L M C$ en dos partes diferentes del artículo 62. El primer supuesto, al que se refiere el artículo $62.1^{\circ}$ de la $L M C$, es "la buena o mala fe" (supuestos que constituyen criterios para determinar el "quantum" de la compensación económica) y el segundo, está regulado en el artículo $62.2^{\circ}$ de la $L M C$. Esta segunda regulación se aplica respecto del cónyuge culpable del divorcio, que puede perder su derecho a la compensación o ser disminuido prudencialmente por el juez. Así, no parece razonable que el artículo 62 de la $L M C$ recurra en dos ocasiones a la mala fe del cónyuge beneficiario, como causal de rebaja de la pensión compensatoria. La explicación de esta aparente reiteración consistiría en que el inciso $2^{\circ}$ es más restringido en su ámbito de aplicación, que el inciso $1^{\circ}$, por cuanto éste procede también respecto de la nulidad. Una segunda diferencia es que en el inciso primero no sólo se refiere a la mala fe, sino también a la buena fe por lo que dicho inciso considera la buena fe del cónyuge beneficiario para aumentar el "quantum" de

buena o mala fe como criterio de determinación del «quantum» por cuanto el fallo se sustenta en que no se dan los requisitos de procedencia de la figura establecidos en el artículo 61 de la LMC.

115 La doctrina entiende que la buena fe no se refiere sólo al demandante, sino a ambas partes a falta de una referencia explícita de la norma. TURNER (2005), p. 500. Sin perjuicio de lo cual, GómeZ DE LA TORRE entiende que la buena o mala fe se refiere al cónyuge beneficiario en la medida que ha provocado la ruptura. Gómez de la Torre (2005), p. 14. Turner (2004), p. 500 y Gómez de la Torre (2005), p. 14.

116 Estas posiciones combinan de una forma bastante aceptable las tesis contrapuestas en consideración a las cuales, por una parte, el matrimonio sería un contrato y, por la otra una institución. De esta forma el matrimonio en cuanto a su constitución es un contrato, por cuanto debe cumplir con los requisitos de existencia y validez del acto jurídico, pero una vez constituido es una institución. 
la compensación. Una última forma de diferenciar el ámbito de aplicación de estos incisos, que se refieren a la mala fe del cónyuge beneficiario, es entender que el artículo $62.1^{\circ}$ de la $L M C$ no exige la calificación del cónyuge beneficiario como culpable, por cuanto dicha circunstancia estaría contemplada en el artículo $62.2^{\circ}$ de la $L M C^{117}$. Nos parece entonces que la norma precedente, cuando establece que "si se decretare el divorcio en virtud del artículo 54, el juez podrá denegar la compensación económica que habría correspondido al cónyuge que dio lugar a la causal, o disminuir prudencialmente su monto", está exigiendo una calificación de gravedad adicional al divorcio culpable. De lo contrario al juez se le hubiese obligado a denegar o disminuir la compensación económica ${ }^{118}$. En el Derecho español es posible, plantear la misma interpretación por cuanto el juez, conforme al artículo 97, $\mathrm{N}^{\circ} 9$ del $C C E$, puede, en la determinación del "quantum", tener en cuenta "cualquier otra circunstancia relevante ${ }^{\prime 119}$. Entonces, dentro de dichas circunstancias relevantes, se puede considerar el incumplimiento de los deberes del matrimonio, por lo que, como hemos visto, el incumplimiento de deberes conyugales en nuestro Derecho tendría efectos, por lo que la procedencia de la responsabilidad extracontractual debe reducirse a casos especiales, como los precedentemente analizados ${ }^{120}$. Así tenemos que la imputabilidad agravada, como presupuesto sancionatorio, en la

117 La referida norma faculta al juez para denegar o reducir prudencialmente el monto de la compensación respecto del cónyuge culpable. Ésta es la única interpretación posible, si no se quiere entender que simplemente se trata de una reiteración. En contra está TURNER que entiende que una graduación de la culpa, que lleve a determinar el "quantum", exige el reconocimiento de dicha graduación. TURNER (2005), p. 499. Por otra parte, otros autores, como CorRal, simplemente entienden que la buena o mala fe del cónyuge beneficiario no influye por cuanto a éste se le aplica el artículo $62.2^{\circ}$ de la LMC.

118 VARGAS se opone a esta posibilidad, por cuanto la compensación económica, de acuerdo al artículo 61 de la LMC, tendría como fundamento que: "[...] se [le] compense [al cónyuge débil] el menoscabo económico sufrido por esta causa". Sin embargo, para VARGAS, la norma precedente, establece los requisitos de procedencia de la compensación económica, pero no se refiere para nada a la determinación del "quantum". El artículo 62 de la LMC se refiere a la mala fe como criterio de determinación del "quantum", y, conforme el análisis de VARGAS, sólo se aplica hasta el monto del desequilibrio patrimonial. No compartimos dicho criterio por cuanto éste, vacío de contenido, debe ser llenado por la buena y mala fe, que es una consideración ética, que excede la función resarcitoria, y por ende va más allá de la mantención del equilibrio patrimonial entre los cónyuges. VARGAS (2009), pp. 170-175.

${ }^{119}$ El artículo 97 del CCE dispone que: "[e]l cónyuge al que la separación o el divorcio produzca un desequilibrio económico en relación con la posición del otro, que implique un empeoramiento en su situación anterior en el matrimonio, tendrá derecho a una compensación que podrá consistir en una pensión temporal o por tiempo indefinido, o en una prestación única, según se determine en el convenio regulador o en la sentencia. A falta de acuerdo de los cónyuges, el Juez, en sentencia, determinará su importe teniendo en cuenta las siguientes circunstancias: [...] 9. ${ }^{a}$ Cualquier otra circunstancia relevante. [...]". Véase Díaz (2013), p. 1017.

${ }^{120}$ La tesis aquí planteada es novedosa por cuanto, a pesar del tenor literal del artículo 62 de la LMC -en lo que respecta a la buena y mala fe-, revisada la jurisprudencia en materia de compensación económica, no hay referencia a la mala fe en los términos analizados precedentemente. 
determinación del «quantum» de la compensación económica, está implícito en la legislación del matrimonio, lo que hace que ésta pueda ser un criterio aplicable a la responsabilidad civil por infracción a deberes estatutarios del matrimonio.

\section{Jurisprudencia chilena}

En los últimos años tímidamente se están comenzando a dictar fallos que se refieren a la indemnización de daño moral por incumplimiento de deberes extrapatrimoniales y del matrimonio ${ }^{121}$.

Un fallo de la ICA de Rancagua, de 29 de octubre del 2007, en los autos Rol No 672-2007, desechó la pretensión indemnizatoria por daño moral de la demandante por violación grave y reiterada de los deberes del matrimonio. En concreto la sentencia resuelve: "[c]abe señalar que este rubro no lo contempla la Ley 19.947 (se refiere al daño moral), razón suficiente para que sea rechazado su pago (...) La extrapolación que pretende la apelante del pago del daño moral en los términos que señala [el artículo] 2329 del Código Civil al ámbito de familia, no resulta pertinente, puesto que, situado dicho pago sólo en el ámbito extracontractual, recientemente se ha extendido a la responsabilidad contractual, integración que aún no alcanza a aquellas situaciones que por el cese de la vida en común puedan afectar seriamente a uno o a ambos cónyuges recíprocamente, y que impliquen aquellos sufrimientos a que se refiere el apelante" (lo agregado entre paréntesis es nuestro) ${ }^{122}$. En igual sentido, una sentencia de la CA de Puerto Montt, de 20 de diciembre del 2010, en autos Rol No 181-2010, desechó un acuerdo celebrado entre marido y mujer por el cual la mujer suscribió veinticuatro cheques de un millón cada uno por haber tenido una relación extramatrimonial. La Corte estimó que el acuerdo adolecía de causa, lo que alcanzaba a los cheques por cuanto éste es un instrumento

121 Respecto de la competencia se ha entendido que la competencia es de los tribunales civiles. El fallo de la CS, de fecha 17 de diciembre del 2008, en autos rol № 5298-08, resuelve que un TF no tiene competencia para conocer en un procedimiento ordinario de familia de una demanda de indemnización de perjuicios, presentada por el ex marido, contra su ex mujer y madre de sus hijos, por la cual aquél contribuyó a la mantención de la menor que en realidad no era su hija, gracias al actuar doloso de la demandada. Número de identificador Microjuris: MJCH_MJJ19126. Ello sin perjuicio que una sentencia de la Corte de Apelaciones de Concepción, de fecha 25 de octubre del 2007, en autos Rol No 909-2007, resuelve que "[d]entro del concepto de relaciones de familia se comprenden indudablemente los derechos y deberes recíprocos que el matrimonio impone a los cónyuges, que se regulan fundamentalmente en los artículos 131 y siguientes del Código Civil, como son el deber de fidelidad, de socorro, de ayuda mutua o asistencia, de respeto y protección recíprocos, derecho y deber de vivir en el hogar común, de cohabitación, de auxilio y de expensas para la litis. Por consiguiente, si tales son las relaciones de familia de orden personal que el matrimonio genera entre los cónyuges, forzoso es concluir que una demanda, aunque sea de indemnización de perjuicios, que se funde en la infracción de alguno de los deberes antes señalados, es de competencia del Juzgado de Familia".

122 Número de identificador Lexis Nexis: 38473. 
abstracto, pero sólo en cuanto a tercero. Ello por aplicación de la Ley № 18.092 al cheque, conforme al artículo $11.3^{\circ}$ del $D L 707$. De este modo, la Corte estimó, en cuanto al fondo del acuerdo, que carecía de causa por cuanto el daño moral en nuestro ordenamiento jurídico no se indemniza en sede contractual (fundamento décimo tercero de la sentencia). Y agrega, en el considerando siguiente, que el pretender una indemnización de perjuicio por relaciones extramatrimoniales adolecería de causa ilícita e iría contra la regulación del adulterio, que es una normativa de orden público cuya transgresión no genera indemnización de perjuicios. Finalmente, en el considerando décimo séptimo resuelve que el pacto adolecería también de objeto ilícito. En resumidas cuentas la Corte estaría aplicando el principio de especialidad.

Una sentencia reciente de la Corte Suprema, de 13 de junio del 2012, Rol № 263-2010, también desechó la indemnización por daño moral por incumplimiento de deberes en el matrimonio, recurriendo al principio de la especialidad. El fallo rechazó una demanda por daño moral de un marido contra su mujer y un tercero con quien habría mantenido relaciones sexuales en circunstancias que una de sus hijas matrimoniales habría sido hija del demandado. A pesar que estas circunstancias se prueban en el juicio, la sentencia de primera y segunda instancia, confirmada por la Corte Suprema, desechó la demanda. En el considerando cuarto, del fallo de la Corte Suprema se resuelve que "[...] el adulterio no es fuente de la responsabilidad extracontractual"123. Por su parte, la sentencia de Corte Suprema, Causa No 778/2011 (Sala Primera Civil), de 6 de

${ }^{123}$ La sentencia de segunda instancia es de la Octava Sala de la CA de Santiago, de 10 de noviembre del 2009, pronunciada en autos "Prado con Alcalde y otro", Rol № 7738-07. En este sentido en el referido fallo se resuelve lo siguiente: DÉCIMO NOVENO: Que, en consecuencia, teniendo presente el cúmulo de disposiciones que sancionaban y sancionan el adulterio, es posible concluir que el adulterio, desde siempre, ha sido calificado por el legislador como infracción grave al deber de fidelidad de los cónyuges y no como delito o cuasidelito civil. En efecto, los diferentes ordenamientos jurídicos han tratado de mantener los conflictos matrimoniales dentro de cierto grado de discreción, por lo cual, los legisladores, anticipándose al conflicto, han precisado las consecuencias de la infracción, como en el caso de autos, al deber de fidelidad. Es decir, el derecho de familia por su especialidad, contempla sus propias sanciones, no siendo aplicable en consecuencia, las normas generales sobre responsabilidad civil y por ende no corresponde -en un caso como el de autos- solicitar ni mucho menos conceder la reparación del daño moral. VIGÉSIMO: Que, desde otro punto de vista, y tan sólo como un ejercicio intelectual, si se consideraran aplicables las normas del derecho común, tampoco sería posible considerar que el adulterio constituya un hecho ilícito civil. En efecto, si se tiene en consideración -que los delitos se caracterizan por el dolo y los cuasidelitos por la culpa- resulta en extremo dificultoso concebir que un adulterio se haya cometido por uno de los cónyuges con el propósito único y deliberado de causar daño al otro cónyuge, como así también, resulta difícil de imaginar un adulterio cometido simplemente por culpa o negligencia. El adulterio, como fenómeno sociológico de la humanidad, no puede encuadrarse bajo los parámetros de la responsabilidad civil extracontractual. VIGÉSIMO PRIMERO: Que, finalmente, el hecho que el adulterio siempre haya tenido una sanción especial, establecida por el legislador en consideración a la naturaleza de la institución del matrimonio, piedra fundamental del derecho de familia, no permite considerarlo fuente de responsabilidad extracontractual como lo pretende el demandante, pues la normas que regulan tales materias se refieren a la reparación de 
marzo de 2012 dispone, en su considerando primero que: "[n]o serían indemnizables los perjuicios morales causados al cónyuge que ha sufrido por el actuar del otro, acogiendo, por consiguiente, la excepción de nulidad de la obligación por carecer de causa real y lícita"124. La sentencia de la Corte Suprema (Cuarta Sala Especial) de 14 de octubre de 2011, desechó la acción de indemnización de perjuicios, declarando la incompetencia del tribunal de instancia (tribunal de familia), correspondiendo el conocimiento y fallo de estos asuntos al juez de letras en lo civil competente ${ }^{125}$. Por su parte, también el Tribunal Constitucional desechó un recurso de inaplicabilidad por inconstitucionalidad, por estimar que "[d]e la institución matrimonial no surgen inmediata y directamente derechos susceptibles de apreciación pecuniaria y considerando que el contenido esencial del dominio lo constituye el valor y no la materialidad de la cosa, no puede sino concluirse que sobre tales derechos incorporales no puede recaer la propiedad; es decir, no se trata de derechos propietarizables, en cuanto no tienen contenido o provecho económico inmediatos ${ }^{\prime 126}$. Un interesante fallo de la Sala Primera, de la Corte de Apelaciones de Talca, № 24458, de 31 de Agosto de 2012, Ingreso Corte $N^{\circ} 133 / 2012$, admitió esta posibilidad, aunque, en definitiva, desechó la demanda. La sentencia del tribunal "a quo" niega la aplicación de la responsabilidad civil por infracción a los deberes del matrimonio; pero la Corte de Apelaciones, a pesar que se inclina por su aplicación, confirma la sentencia por falta de prueba de los elementos de la responsabilidad civil. De este modo, el fallo resuelve, en su considerando duodécimo, que "[...] sin entrar a analizar el cumplimiento de cada uno de estas exigencias en el caso sub lite, esta Corte concuerda con lo razonado por el juez de la instancia, toda vez, que aun cuando nos inclinemos por la aceptación de la responsabilidad civil en el seno del matrimonio, de acuerdo con las reglas generales de todo sistema de responsabilidad, el daño producido debe ser el resultado natural de la conducta antijurídica e imputable de su autor, esto debe ser atribuible causal y normativamente a la conducta dolosa o culpable desplegada por el autor. En la especie, no ha podido comprobarse supuestos que descartan en su esencia que pueda darse por establecida la relación de causalidad entre las infidelidades (verdaderas o conjeturadas del marido) y el contagio de la mujer del virus del papiloma humano, para ello sería necesario descartar que la misma mujer no

daños derivados de obligaciones de carácter patrimonial, motivo por el cual no resulta jurídicamente procedente acoger la presente demanda". Identificador Microjuris: MJJ31795.

124 Id. vLex: VLEX-436244906.

${ }^{125} \mathrm{CL} / J U R / 8275 / 2011$. En este mismo sentido, se puede citar la sentencia de casación de la Corte Suprema (Cuarta Sala Mixta) de 28 de septiembre de 2012, Causa № 6200/2010, Resolución Nº 79733. Id. vLex: VLEX-436785398.

126 Sentencia del TC, Rol No 1490-09-INA, 31 de marzo del 2009, c. $15^{\circ}$. 
hubiera sido portadora del mismo virus con anterioridad (gran porcentaje de los adultos lo portan), que el marido no lo hubiera contraído antes de contraer matrimonio (caso en el cual la infidelidad no sería la causa del daño), entre varias otras hipótesis posibles de imaginar, que hacen imposible dar por establecido el nexo causal entre las supuestas infidelidades del marido y el cáncer padecido por su mujer. Al respecto debe tenerse en cuenta que la infección por el papiloma humano es la infección de transmisión sexual más frecuente en el mundo y que tal como consta en el informe acompañado a fojas 133, en la mayoría de las mujeres con virus del papiloma humano la infección se produce antes de los veinticinco años suele durar de ocho a diez meses y en condiciones de inmunidad habituales, es eliminada en la mayoría de los casos, solo persiste el $10 \%$ de las infecciones a los treinta y cinco años (I. Gómez García, et al/ Actas Urol Esp. 2005; 29 (4) 365-372)"127. En igual sentido resolvió una sentencia reciente, en autos "Moller con Moller", ante el $10^{\circ}$ Juzgado Civil de Santiago, causa Rol No C-9243-2012. En dicha causa el tribunal de primera instancia, reconociendo la procedencia de la responsabilidad extracontractual respecto de un padre que no había reconocido voluntariamente a una hija y respecto de la cual no se había preocupado en lo absoluto, resolvió que la actora no acreditó la culpa ${ }^{128}$. Ambos fallos, aunque interesantes, son criticables por cuanto no sustentan adecuadamente la aplicación de la responsabilidad extracontractual al incumplimiento de deberes extrapatrimoniales. Sin perjuicio que la crítica precedente es injusta por cuanto en definitiva las sentencias no dan lugar a la responsabilidad extracontractual, se echa de menos el que los fallos hayan desechado la responsabilidad civil sin recurrir a un mayor análisis respecto de este tema. El segundo fallo además desconoce los criterios de imputación objetiva, desde que reconoce la falta de reconocimiento de filiación y el incumplimiento de los deberes inherentes a la filiación por parte del padre, lo que debería considerarse como un incumplimiento calificado del estatuto filiativo, que daría lugar a la responsabilidad civil. Naturalmente, este razonamiento es plenamente aplicable al estatuto del matrimonio.

\footnotetext{
$127 \mathrm{Cl} / \mathrm{JUR} / 1094 / 2012$.

${ }^{128}$ En este sentido el referido fallo resuelve que "VIGÉSIMO TERCERO: Que, constituyen presupuestos necesarios para hacer nacer una responsabilidad extracontractual, en los términos de los artículos 2314 y siguientes del Código Civil, que exista un acto o hecho del o los demandados que se haya realizado con dolo o culpa, que se irroguen perjuicios para el demandante y se verifique una relación de causalidad entre tal acto o hecho y los daños sufridos".

El fallo es criticable por cuanto, de lo señalado en sus considerandos, se desprende que el padre reconocido forzosamente por no comparecencia no se ocupó de su hija, lo que naturalmente constituye una causal de imputación objetiva. Al parecer la sentencia entiende la imputabilidad únicamente en sentido subjetivo (ver considerandos vigésimo sexto y séptimo del fallo). Véase: BARCIA (2006a) y (2007b).
} 
La tesis que hemos planteado por tanto podría dar luces de solución a muchos casos en que habiendo infracción estatutaria en el matrimonio, es necesario recurrir a algún criterio adicional que determine la responsabilidad civil, como lo sería: la gravedad o profundidad de la violación del estatuto matrimonial.

\section{Conclusiones}

\section{VIII.1. Conclusiones generales}

El planteamiento general, en torno a la indemnización de perjuicios por incumplimiento de deberes extrapatrimoniales en el matrimonio, es que, aún generándose daño moral, la indemnización en principio no procede, salvo los casos especiales previamente analizados. Además, de los argumentos precedentemente planteados, respaldan esta conclusión, los principios de la intervención mínima del Estado y la dignidad del ser humano, que impiden que la esfera íntima de las personas sea violentada por el Estado. Sin perjuicio de lo anterior, como se ha estudiado, ésta es sólo una regla general por cuanto en caso de responsabilidad penal, de ilícitos agravados, que generan violación a otros estatutos jurídicos, aunque no se genere tutela penal, y en especial en la medida que se violenten derechos fundamentales, naturalmente procederá la indemnización de perjuicios. Además, conforme a los argumentos que ya se han dado, un ilícito civil agravado puede dar lugar a la indemnización de perjuicios, pero la justificación estatutaria de la responsabilidad no está en el Derecho matrimonial.

Por ello también debemos concluir que, a pesar que el reconocer una acción de perjuicios por incumplimiento de deberes en el matrimonio es sumamente invasiva del Estado de Derecho -porque debemos tomar consciencia en que lo que estamos cediendo a nuestros jueces: la calificación jurídica de nuestra moralidad-, esta cesión se hace indispensable en un Estado de Derecho moderno, respetuoso de los derechos fundamentales. Lo único que le pediríamos a los jueces es que en sus fallos no trasunten sus creencias morales, por cuanto lo que les estamos solicitando es que determinen "lo bueno" y "lo malo" de nuestro comportamiento ético, por lo que a los menos exigimos criterios objetivos y claros para su determinación, como los que se sugieren en la presente investigación.

\section{VIII.2 Conclusiones específicas}

a. La jurisprudencia chilena en principio ha acogido los argumentos contrarios a la responsabilidad civil por incumplimiento de deberes estatutarios del matrimonio (con los matices que se han señalado). A pesar que dicha tesis es correcta es sólo una regla general. Conforme a lo señalado en el presente 
trabajo si bien el incumplimiento de cualquier deber del matrimonio no puede generar responsabilidad civil -como por ejemplo la trasgresión al deber de convivencia, socorro o mantener relaciones sexuales- en la medida que dicho incumplimiento sea agravado debería generarla.

b. Los casos más evidentes de ilícitos agravados, ya han sido analizados, pero naturalmente puede haber otros. El más evidente es la responsabilidad penal -respecto de la cual también se plantearon excepciones-, los incumplimientos que generen violación de derechos fundamentales, y finalmente los casos agravados por la aplicación de otro estatuto jurídico. En realidad esta es una de las conclusiones que nos parece más destacable del presente trabajo, por cuanto el ilícito infraccional no vendría dado sólo por la trasgresión del estatuto del matrimonio, sino por la violación de otro estatuto de relevancia: libertad sexual, el estatuto del trabajo, discriminación por razón de sexo (por ejemplo una intriga que planea un cónyuge para que el otro sea despedido porque desea que esté en la casa), etc.

\section{BibliOgRAFÍA CITADA}

Algarra Prats, Esther (2012): "Incumplimiento de deberes conyugales y responsabilidad civil", en: Moreno Martínez, Juan Antonio (Coordinador) La responsabilidad civil en las relaciones familiares (Madrid, Editorial DYKINSON, S. L.), pp. 11-60.

Alpa, Guido; Bessone, Mario y Zeno-Zencovich, Vincenzo (1995): Trattato di Diritto privato. Obbligazioni e Contratti-VI, seconda edizione (Torino, Diritto da Pietro Rescigno, Unione Tipografico-Editrice Torinese).

BarCeló DoméneCH, Javier (2012): "El criterio de imputación de la responsabilidad civil en el ámbito familiar", en: MOReno Martínez, Juan Antonio (Coordinador) La responsabilidad civil en las relaciones familiares (Madrid, Editorial Dykinson), pp. 79-128.

Barcia Lehmann, Rodrigo (2006a): "La Asimilación de la Culpa al Dolo desde una Perspectiva Objetiva del Derecho de los Contratos", en: Revista lus et Praxis (año 12, № 2), pp. 75-94.

(2007b): "La Asimilación de la Culpa al Dolo desde una Perspectiva Objetiva del Derecho de los Contratos", en: Revista lus et Praxis (año 13, No 1), pp. 29-44.

(2011c): Fundamentos del Derecho de Familia e Infancia (Santiago, Thomson).

Barcia Lehmann, Rodrigo y Riveros Ferrada, Carolina (2011a): "El Carácter Extrapatrimonial de la Compensación Económica", en: Revista Chilena del Derecho (Vol. 38, № 2), pp. 249-278. 
(2011b): “El Carácter Extrapatrimonial de la Compensación Económica y su Renuncia", en: Revista de Derecho de la Pontificia Universidad Católica de Valparaíso (Vol. 37, № 2), pp. 93-113.

Barrientos Grandón, Javier (2007): "La Compensación Económica como 'Derecho de uno de los Cónyuges y Obligación Correlativa del Otro'. De sus Caracteres", en: Revista Chilena de Derecho Privado (№ 9).

(2011): Derecho de las personas: El derecho matrimonial (Santiago, Abeledo Perrot Thomson Reuters).

Barros Bourie, Enrique (2006): Tratado de responsabilidad extracontractual (Santiago, Editorial Jurídica de Chile).

BénABent, Alain (2010): Droit civil: Droit de la famille (París, Montchrestien).

Buoncristiano, Mario; Cirillo, Gianpiero Paolo; Cuffaro, Vincenzo y Roselli, Federico (1997): "Codice civile", a cura di Pietro Rescigno (Milano, Giuffrè).

Bustos Moreno, Yolanda (2012): "El resarcimiento del daño causado por la falta de reconocimiento en la filiación no matrimonial", en: Moreno MARTínez, Juan Antonio (Coordinador) La responsabilidad civil en las relaciones familiares (Madrid, Editorial Dykinson), pp. 129-159.

Céspedes Muñoz, Carlos y Vargas Aravena, David (2008): "Acerca de la naturaleza jurídica de la compensación económica: la situación en Chile y en España", en: Revista Chilena de Derecho (Vol. 35, № 3), pp. 439-462.

Scicchitano, Sergio (2012): Code Civile e Legi Complementari (Milano, Giuffrè). Corral TalCIANı, Hernán (2010): “Rodríguez Guitián, Alma María, Responsabilidad civil en el Derecho de familia: especial referencia al ámbito de las relaciones paterno-filiales, Civitas, Madrid, 2009, 336 pp. [Recensión]", en: Revista Chilena de Derecho (Vol. 37, № 1), pp. 177-181.

Claro Solar, Luis (1992): Explicaciones de Derecho Civil Chileno y Comparado: De las Personas (Bogotá, Editorial Jurídica de Chile) Tomo II.

CoRnu, Gérard (2006): Droit civil: La famille (París, Montchrestien, 9 édition).

De Verda y Beamonte, José Ramón (2012): "Resarcimiento de daño moral por intromisión ilegítima del otro cónyuge", en: Moreno Martínez, Juan Antonio (Coordinador), La responsabilidad civil en las relaciones familiares (Madrid, Editorial Dykinson), pp. 161-194.

Díaz Martínez, Ana (2013): "Artículos 42 a 106", en: Bercovitz Rodriguez-Cano, Rodrigo (director), Comentarios al Código civil, Tomo I (Valencia, Tirant Lo Blanch), pp. 637-1108.

Dı Majo, Adolfo (2012): Codice civile. Con la Costituzione, i Tratati U. E. e le principali norme complementari (Milano, Giuffrè Editore).

Domínguez Guiltén, María Candelaria (2012): La convivencia familiar (antiguo derecho de visitas) (Caracas, Ediciones Paredes II). 
Domínguez Hidalgo, Carmen (2012): "El principio de reparación integral del daño y su contenido: algunas consecuencias para el Derecho chileno", en: Estudios de Derecho Civil V. Jornadas Nacionales de Derecho Civil, Concepción (Santiago, AbeledoPerrot LegalPublishing), pp. 671-685.

EIRANOva Encinas, Emilio (1998): Código Civil Alemán Comentado. BGB (Madrid, Marcial Pons).

FerRer RibA, Joseph (2001): "Domestic relations". Disponible en: <http://www. indret.com/>

Franzoni, Massimo (1993): "Dei fatti illeciti. Art. 2043-2059", en: Commentario del Codice civile, Scialoja-Branca, Libro quarto-delle obbligazioni (Bologna, Zanichelli Editore), pp. 1-1301.

Galgano, Francesco (2001): "Dizionario enciclopédico della giurudenza civile", a cura di Massino Franzoni (Padova, Casa Editrice Dott Antonio Milani).

Gómez de LA TORRe, Maricruz (2005): Compensación Económica en la Nueva Ley de Matrimonio Civil (Seminario, Colegio de Abogados de Santiago de Chile), p. 14.

IzQuierdo Tolsada, Mariano (1997): Aspectos civiles del nuevo Código penal. (Responsabilidad civil, tutela del derecho de crédito, aspectos de Derecho de familia y otros extremos) (Madrid, Dykinson).

Larrocau García, María Matilde (2010): "Incumplimiento de las obligaciones conyugales y en especial del deber de fidelidad como fuente generadora de responsabilidad civil: A propósito de un fallo pronunciado por el Tribunal Superior de Justicia de Brasil", en: Revista Chilena de Derecho de Familia (No 2), pp. 99-124.

Le Torneau, Philippe (2004): La Responsabilidad Civil (Traducc. Javier Tamayo Jaramillo, Bogotá, Editorial Legis).

LÓPEZ DE LA CRUZ, Laura (2010): "El resarcimiento del daño moral ocasionado por el incumplimiento de los deberes conyugales", en: Revista para el Análisis del Derecho, InDret, 4, Disponible en: <http://www.indret.com/>

Medina, Graciela (2002): Daños en el Derecho de familia (Buenos Aires, Rubinzal-Culzoni Editores).

(2008): Daños en el Derecho de Familia (Buenos Aires, Rubinzal-Culzoni Editores).

Mendoza Alonso, Pamela (2011): “Daños morales por infidelidad matrimonial. Un acercamiento al Derecho español", en: Revista Chilena de Derecho y Ciencia Política (Vol. 2, № 2), pp. 41-64.

Meza Barros, Ramón (1979): Manual de Derecho de la Familia: Colecciones Manuales Jurídicos (Santiago, Editorial Jurídica). 
Münchener Kommentar Zum Bürgerlichen Gesetzbuch (2009): Band 5, Schuldrecht, Besonderer Teil III, §£ 705-853, Partnerschaftsgesellschaftsgesetz, Produkthaftungsgesetz, redakteur Mathias Habersack, 5. Auflage, Verlag C. H. Beck, München.

Münchener Kommentar Zum Bürgerlichen Gesetzbuch (2000): Band 7, Familienrecht I, §§ 1297-1588, Vahrg, Vaüg, Hausrats V, redakteur Kurt Rebmann, 4. Auflage, C. H. Beck'sche Verlagsbuchhandlung, München.

Ortiz de Rozas, Abel (2001): "Responsabilidad por daños y perjuicios entre cónyuges", en: Revista de Derecho de Daños. Daños en las relaciones de Familia (No 1), pp. 167-188.

OtÁROla EsPINOZA, Yasna (2012): "La culpa en materia de Derecho matrimonial", en: Estudios de Derecho Civil VIII. Jornadas Nacionales de Derecho Civil, Santa Cruz (Santiago, LegalPublishing-Thomson Reuters), pp. 125-134.

Pizarro Wilson, Carlos (2004): "La Compensación Económica en la Nueva Ley de Matrimonio Civil", en: Revista Chilena de Derecho Privado ( $N^{\circ} 3$ ).

Pizarro Wilson, Carlos y Vidal Olivares, Álvaro (2009): La Compensación Económica por Divorcio o Nulidad Matrimonial (Santiago, LegalPublishing Abeledot Perrot).

Ramos MAestre, Áurea (2012): "La responsabilidad civil por el incumplimiento del derecho de visitas", en: Moreno Martínez, Juan Antonio (Coordinador), La responsabilidad civil en las relaciones familiares (Madrid, Editorial Dykinson), pp. 383-407.

Roca I TRíAs, Encarna (2000): "La responsabilidad civil en el Derecho de familia. Venturas y desventuras de cónyuges, padres e hijos en el mundo de la responsabilidad civil", en: Moreno Martínez, Juan Antonio (Coordinador) Perfiles de la responsabilidad civil en el nuevo milenio (Madrid, Editorial Dykinson), pp. 533-563.

Rodríguez Guitán, Alma María (2011): "De nuevo sobre la reparación de los daños en el ámbito del matrimonio: a propósito de la STS de 14 de julio de 2010", Diario la Ley, Disponible en: <http://www.indret.com/>

(2009): Responsabilidad civil en el Derecho de familia: especial referencia al ámbito de las relaciones paterno-filiales (Navarra, Editorial Aranzadi, S.A.).

Romero Coloma, Aurelia María (2011): Incumplimiento de deberes conyugales y derecho a indemnización (Madrid, Editorial Reus).

(2008): La indemnización entre cónyuges, excónyuges y parejas de hecho (Valencia, Tirant Lo Blanch).

(2009): Reclamaciones e indemnizaciones entre familiares en el marco de la responsabilidad civil (Barcelona, Editorial Bosch, S.A.). 
Ruz LaRTIGA, Gonzalo (2009): "La reparación integral del daño: ¿mito o realidad?", en: Estudios de Derecho Civil IV. Jornadas Nacionales de Derecho Civil, Olmué (Santiago, AbeledoPerrot LegalPublishing), pp. 672-677.

Sáinz-Cantero Caparrós, María Belén y Pérez Vallejo, Ana María (2012): Valoración y reparación de daños entre familiares. Fundamentos para su reclamación (Granada, Editorial Comares).

SelLA, Mauro (2010): I danni non patrimoniali (Milano, Giuffrè). (2011) "I nuovi illeciti. Danni patrimoniale e non patrimoniale" (Torino, Wolters Kluwer Italia).

Schulze, Reiner (2005): Bürgerliches Gesetzbuch, Handkommentar. 4. Auflage (Baden-Baden, Verlagsgesellschaft).

Segura Riveiro, Francisco (2003): "La Compensación Económica al Cónyuge más Débil", en: Revista de Derecho, Universidad de Concepción, Facultad de Ciencias Jurídicas y Sociales ( $N^{\circ} 214$, Año LXXI, julio-diciembre), pp. 109-125.

Sella, Mauro (2011): I nuovi illeciti: Danni patrimoniale e non patrimoniale (Torino, Wolters Kluwer Italia). (2010), I danni non patrimoniali (Milano, Giuffrè).

Severín Fuster, Gonzalo (2008): "Indemnización entre cónyuges por los daños causados con ocasión del divorcio", en: Estudios de Derecho Civil III. Jornadas Nacionales de Derecho Civil, Valparaíso, 2007 (LegalPublishing, Santiago de Chile), pp. 99-140.

SESTA, Michele (2012): "Infracción de los deberes familiares y responsabilidad: la experiencia italiana", en: Moreno Martínez, Juan Antonio (Coordinador) La responsabilidad civil en las relaciones familiares (Madrid, Editorial Dykinson), pp. 409-436.

Terre, Francois y Fenouillet, Dominique (2005): Droit civil: Les personnes. La famille. Les incapacités (París, Dalloz).

Turner Saelzer, Susan (2004): "Las Prestaciones Económicas entre Cónyuges Divorciados en la Nueva Ley de Matrimonio Civil", en: Revista Derecho (Valdivia) (Vol. XVI, julio 2003), pp. 83-104.

(2012): "Deberes personales derivados del matrimonio y daños en la jurisprudencia chilena", en: Estudios de Derecho Civil VIII. Jornadas Nacionales de Derecho Civil, Santa Cruz (Santiago, LegalPublishing-Thomson Reuters), pp. 165-173.

TrabucCHI, Cian (2009): Commentario breve al Codice civile, $9^{\text {a }}$ edizione a cura di CIAN Giorgio (Padova, Casa Editrice Dott. Antonio Milani).

Valenzuela del Valle, Jimena (2012): “Responsabilidad civil por el incumplimiento de obligaciones matrimoniales y por el ejercicio abusivo del divorcio 
unilateral: un estudio de su admisibilidad en Chile", en: Revista de Derecho Unversidad Católica del Norte (Vol. 19, No 1), pp. 241-269.

Vargas Aravena, David (2009): Daños civiles en el matrimonio (Madrid, Wolters Kluwer España).

Vidal Olivares, Álvaro (2004): “La Compensación Económica en la Ley de Matrimonio Civil. ¿Un Nuevo Régimen de Responsabilidad Civil Extracontractual?", en: Revista de Derecho (№ 215-216, Universidad de Concepción, Año LXXII), pp. 265-287.

Zıviz, Patricia (1991): "Art. 2059", en: Cendon, Paolo (Director) Commentario al Codice civile, volumen quarto, artt. 1655-2059 (Torino, Unione TipograficoEditrice Torinese), pp. 2176-2194. 